\title{
EL DERECHO A UNA VIVIENDA DIGNA EN EL DERECHO INTERNACIONAL Y CONSTITUCIONAL COMPARADO (NOTAS PARA UN PROYECTO DE LEY ASTURIANA DE GARANTÍA DEL DERECHO A LA VIVIENDA DIGNA)*
}

\author{
BENITO ALÁEZ CORRAL ${ }^{* *}$
}

\begin{abstract}
RESUMO: Com a finalidade de oferecer algumas diretrizes dogmático-constitucionais ao legislador do Principado de Astúrias, faz-se nesse artigo uma análise crítica dos modelos de garantia do direito a uma moradia digna reconhecido no art. 47 da Constituição Espanhola e nas normas de direito internacional que vinculam a Espanha, a partir tanto do direito constitucional europeu comparado, quanto da legislação européia comparada. Conclui-se de tal análise que uma futura lei asturiana do direito à moradia digna deveria considerar as disposições urbanísticas e edificatórias que garantem um mínimo de salubridade, habitabilidade, infraestruturas e equipamentos comunitários, localização etc, de toda moradia como um instrumento de garantia da dignidade dessa moradia. A referida lei não deveria conter um direito subjetivo genérico e abstrato à moradia digna - de muito difícil satisfação efetiva, mas sim direitos subjetivos concretos a certas ajudas materiais de acesso e/ou fruição da moradia, atribuídos de qualquer forma não de maneira linear por grupos da população, mas em função da concreta necessidade/ capacidade econômica dos potenciais beneficiários, e subordinados a uma condição suspensiva a ser determinada pelo governo regularmentarmente com base nos recursos disponíveis para cada modalidade de ajuda, de modo que possam ajustar-se às disponibilidades orçamentárias e à necessidade social de cada espécie de auxílio.

PALAVRAS-CHAVE: Direitos Sociais; Direito à Moradia Digna; Direito Constitucional Comparado.
\end{abstract}

ABSTRACT: With the aim of giving the Asturian Principalty Government constitutional guidelines for its housing legislation, this article develops a critical analysis of the existing european comparative law models of safeguarding the right to adequate housing granted by Sec. $47 \mathrm{Sp}$. Const. and different

Artigo recebido em 15.02.2011. Pareceres emitidos em 4.04.2011 e 4.04.2011.

Artigo aceito para publicação em 12.04.2011.

* Este estudio es uno de los resultados del Proyecto de Investigación de la Agencia Española de Cooperación Internacional para el Desarrollo "Los derechos sociales como vía para la remoción de las situaciones de inferioridad. Especial atención a la salud y la educación" (A/022982/09) cuyo investigador principal es Miguel Ángel Presno Linera.

** Universidade de Oviedo, Espanha. 
International Treaties binding Spain. From this analysis follows that a future Adequate Housing Act of the Asturian Parliament should consider building and housing regulations regarding safety, health, occupancy, infrastructures and community equipments, etc..., a safeguarding instrument of the right to adequate housing. Such a Housing Act should not contain a general and abstract right to adequate housing -very difficult to satisfy in practice-, but concrete rights to concrete aids either for accessing a house or for enjoying and living in a house, whose bearers should not be groups of people according to certain needs but each individual according to his/her concrete housing needs and own capacity to provide for it by him/herself. These concrete aids should be expressly condictioned by the law to the financial allowance determined each year by the Government in the Annual Budget for each type of aid.

KEYWORDS: Social Rights; Adequate Housing; Constitutional Comparative Law.

RESUMEN: Con la finalidad de ofrecer unas directrices dogmático-constitucionales al legislador del Principado de Asturias, en este artículo se hace un análisis crítico de los modelos de garantía del derecho a una vivienda digna reconocido en el art. $47 \mathrm{CE}$ y en la normativa internacional vinculante para España, a partir tanto del derecho constitucional europeo comparado, como de la legislación europea comparada. De dicho análisis, se desprende que una futura Ley asturiana del derecho a la vivienda digna debería considerar las disposiciones urbanísticas y edificativas que garantizan un mínimo de salubridad, habitabilidad, infraestructuras y equipamientos comunitarios, ubicación, etc... de toda vivienda como un instrumento de garantía de la dignidad de la vivienda. Dicha Ley no debería contener un genérico y abstracto derecho subjetivo a la vivienda digna -de muy difícil satisfacción efectiva- sino concretos derechos subjetivos a ciertas ayudas materiales de acceso y/o disfrute de la vivienda, atribuidos en todo caso no de forma lineal por grupos de población, sino en función de la concreta necesidad/ capacidad económica de los potenciales beneficiarios, y subordinados a una condición suspensiva a determinar por el Gobierno reglamentariamente con las bases de convocatoria de cada modalidad de ayuda, de modo que puedan ajustarse a las disponibilidades presupuestarias y a la necesidad social de cada tipo de ayuda.

PALABRAS-CLAVE: Derechos Sociales; Derecho a la Vivienda Digna; Derecho Constitucional Comparado.

SUMÁRIO: Introdução; 1 . O direito a uma moradia digna no direito internacional; 2. Modelos comparados de regulação constitucional do direito à moradia digna; 3. Modelos comparados de desenvolvimento legal do direito à moradia digna; 4. O direito à uma moradia digna no sistema constitucional espanhol; Bibliografia básica consultada.

SUMMARY: Introduction; 1 . The right to adequate housing in international law; 2. Models of constitutional regulation of the right to adequate housing in compared law; 3. Models of legal development of the right to adequate housing in compared law; 4. The right to adequate housing in the Spanish constitutional system; Basic References.

SUMARIO: Introducción; 1. El derecho a una vivienda digna en el derecho internacional; 2. Modelos comparados de regulación constitucional del derecho a la vivienda digna; 3 . Modelos comparados de desarrollo legal del derecho a la vivienda digna; 4 . El derecho a una vivienda digna en sistema constitucional español; Bibliografía básica consultada. 


\section{INTRODUCCIÓN}

La conversión de los Estados constitucional-democráticos en Estados sociales ha conllevado que tanto en el derecho internacional sobre derechos humanos, como en el constitucionalismo democrático de los diversos Estados, especialmente los europeos, se haya impuesto desde la segunda guerra mundial la introducción de cláusulas tendentes a garantizar una serie de derechos sociales, bien como derechos fundamentales o bien como fines de Estado, entre ellos el derecho a una vivienda digna. Nuestra Constitución de 1978 se suma ya a ello con las genéricas proclamas de que España es un Estado social y democrático de derecho, dos de cuyos valores superiores son la igualdad y la justicia (art. 1 CE), y de que los poderes públicos han de remover los obstáculos que impiden que la libertad y la igualdad de los individuos y de los grupos en los que se integran sean reales y efectivas (art. 9.2 CE). Pero sobre todo lo hace con la garantía dentro de un capítulo $3^{\circ}$ del Título I de todo un conjunto de principios rectores de la política social y económica, que operan como fines de Estado inspiradores de la legislación y de la práctica judicial (art. 53.3 CE), y entre los que se encuentra el denominado "derecho" a una vivienda digna del art. 47 CE.

El texto que sigue lo constituyen unas notas sacadas de un Dictamen, elaborado, junto con otros colegas del área de Derecho Constitucional de la Universidad de Oviedo para la Consejería de Vivienda y Bienestar Social del Principado de Asturias, sobre las posibilidades y contenido jurídico de una futura Ley asturiana de garantía del derecho a la vivienda digna. En este sentido, un adecuado entendimiento del significado normativo de este principio rector de la política social y económica, de cara a su mejor desarrollo legislativo autonómico, requiere su plena comprensión en el contexto del derecho internacional y del derecho constitucional comparado, por lo menos de los ordenamientos jurídicos más representativos de nuestro entorno. De forma preliminar y muy sumaria se puede decir que fuera de nuestras fronteras la regulación constitucional e internacional del derecho a una vivienda digna se caracteriza en términos generales por tres grandes rasgos:

$1^{\circ}$ la casi general ausencia de reconocimiento en el nivel constitucional o internacional de un auténtico derecho subjetivo prestacional de acceso a la vivienda, directamente exigible ante los tribunales, o ni siquiera de la garantía de una prestación o ayuda material que facilite dicho acceso;

$2^{\circ}$ la existencia generalizada, sin embargo, de mandatos a los poderes públicos para que faciliten dicho acceso y/o lo articulen dentro de las disponibilidades presupuestarias;

$3^{\circ}$ la constatación en la doctrina de los organismos internacionales y en la jurisprudencia constitucional comparada de la vinculación existente entre la garantía del derecho a la vivienda digna y la garantía de algunos aspectos del contenido esencial de otros derechos fundamentales, como el derecho a la intimidad, el derecho a la inviolabilidad del domicilio, el derecho a la tutela 
judicial efectiva, o más genéricamente el derecho a la dignidad de la persona o el derecho a una existencia digna.

Igualmente, ya en el ámbito del desarrollo legislativo del "derecho a una vivienda digna", a pesar de las múltiples diferencias regulatorias existentes en los distintos Estados, también se pueden apreciar algunos rasgos comunes, que merece la pena apuntar ahora de forma sumaria:

$1^{\circ}$ la tendencia a generalizar una diversidad de ayudas estatales para que los individuos con insuficientes recursos puedan participar en el mercado de la vivienda en propiedad y/o alquiler, y así satisfacer su derecho a la misma;

$2^{\circ}$ la regulación técnica, desvinculada de la legislación sobre las ayudas para el disfrute o el acceso a la vivienda, de los requisitos de edificación y urbanización que contribuyen a su dignidad y adecuación, y que se encuentran en legislación urbanística o en códigos de la edificación de distinto origen y rango normativo;

$3^{\circ}$ la minimización del papel asistencial directo del Estado en la satisfacción del acceso a la vivienda mediante un parque de viviendas de titularidad pública (viviendas sociales), y su orientación exclusivamente a la provisión de viviendas para los individuos que se encuentran gravemente marginados o con altas probabilidades de exclusión social, dejando a la colaboración con el sector inmobiliario privado el papel principal en la satisfacción de ese derecho.

Procede entrar más en detalle en esta dispar regulación jurídica del derecho a una vivienda digna en el derecho internacional y comparado, a cuya homogeneización ayudan bien poco las normas internacionales vigentes en esta materia, dado que las mismas poseen un carácter muy abstracto y deliberadamente abierto a múltiples desarrollos y concreciones por parte de los Estados signatarios.

\section{EL DERECHO A UNA VIVIENDA DIGNA EN EL DERECHO} INTERNACIONAL

Es bien sabido que, conforme a la CE de 1978, los tratados internacionales han de ser tenidos en cuenta tanto en su perspectiva de derecho vigente directamente aplicable y no desplazable por ninguna norma infraconstitucional de carácter interno -siempre que hayan sido válidamente celebrados y publicados en España- (art. $96 \mathrm{CE}$ ), como en su vertiente de criterio interpretativo de las disposiciones constitucionales en materia de derechos fundamentales -incluidas las relativas al derecho a la vivienda del art. 47 CE- (art. 10.2 CE). Si nos aproximamos al sector del ordenamiento jurídico más general en su ámbito territorial aplicación, el derecho internacional, nos encontramos en primer término con la circunstancia de que son diversos los documentos internacionales que hacen referencia al derecho a una vivienda digna. De ahí que una referencia, por somera que sea, a los mismos resulte obligada, distinguiendo entre aquéllos instrumentos internacionales que aportan una garantía directa y expresa del derecho a una vivienda digna o 
adecuada, y aquellos otros que inciden indirectamente en dicha garantía mediante la tutela de otros derechos o mediante la exigencia de ciertos estándares de actuación de los poderes estatales en diversos ámbitos relacionados con la vivienda, como por ejemplo, la construcción o la contratación pública.

\section{A) Garantía directa del derecho a la vivienda digna.}

En este sentido, cabe mencionar en primer lugar una serie de instrumentos que contienen una garantía internacional directa del derecho a la vivienda digna, obligando a los Estados signatarios a su protección. Entre ellos se encuentra el 25.1 de la Declaración Universal de Derechos Humanos conforme al cual:

"Toda persona tiene derecho a un nivel de vida adecuado que le asegure, así como a su familia, la salud y el bienestar, y en especial la alimentación, el vestido, la vivienda, la asistencia médica y los servicios sociales necesarios; tiene asimismo derecho a los seguros en caso de desempleo, enfermedad, invalidez, viudedad, vejez u otros casos de pérdida de sus medios de subsistencia por circunstancias independientes de su voluntad." (la cursiva es nuestra).

A ese mismo grupo pertenece el art. 11.1 del Pacto Internacional de Derechos Sociales Económicos y Culturales que establece que:

"Los Estados Partes en el presente Pacto reconocen el derecho de toda persona a un nivel de vida adecuado para sí y su familia, incluso alimentación, vestido y vivienda adecuados, y a una mejora continua de las condiciones de existencia. Los Estados Partes tomarán medidas apropiadas para asegurar la efectividad de este derecho, reconociendo a este efecto la importancia esencial de la cooperación internacional fundada en el libre consentimiento" (la cursiva es nuestra).

Dentro de este primer grupo de instrumentos internacionales que otorgan una garantía directa al derecho a la vivienda se hallan igualmente otros instrumentos normativos de organizaciones internacionales de carácter regional, como el art. 34.3 de la Carta de Derechos Fundamentales de la Unión Europea -a la que remite el art. 6 del Tratado de la Unión Europea- conforme al cual:

"Con el fin de combatir la exclusión social y la pobreza, la Unión reconoce y respeta el derecho a una ayuda social y a una ayuda de vivienda para garantizar una existencia digna a todos aquellos que no dispongan de recursos suficientes, según las modalidades establecidas por el Derecho comunitario y las legislaciones y prácticas nacionales" (la cursiva es nuestra);

O también el art. 31 de la Carta Social Europea (en su versión modificada de 1996 aún no ratificada por España, que solo ha ratificado el texto original 
de la Carta de 1961 que expresamente no se ocupaba del derecho a la vivienda), conforme al cual:

"Para garantizar el ejercicio efectivo del derecho a la vivienda, las Partes se comprometen a adoptar medidas destinadas:

1.- a favorecer el acceso a la vivienda de un nivel suficiente;

2.- a prevenir y paliar la situación de carencia de hogar con vistas a eliminar progresivamente dicha situación;

3.- a hacer asequible el precio de las viviendas a las personas que no dispongan de recursos suficientes" (la cursiva es nuestra).

En dicho texto internacional también se requiere de los Estados parte un "apoyo a la construcción de viviendas adaptadas a las necesidades de las familias" (art. 16) y la no discriminación en materia de alojamiento de los trabajados inmigrantes con relación con el acceso al "alojamiento" (art. 19.4.c), lo que viene a completar el régimen jurídico de protección europea de dicho derecho de acceso a la vivienda.

Por último, también se refieren directamente al acceso a la vivienda de algunos colectivos de personas socialmente desfavorecidas ciertos instrumentos internacionales relativos a las garantías de la eliminación de toda discriminación de algunos grupos de individuos, por razón de género (art. 14.2.h, de la Convención de la ONU para la eliminación de todas las formas de discriminación contra la mujer de 1979), por razón de raza (art. 5.e.iii, de la Convención de la ONU sobre eliminación de todas las formas de discriminación racial de 1965), o por razón de edad (art. 27.1 de la Convención de la ONU sobre derechos del niño de 1989).

La aplicación de las disposiciones mencionadas por parte de los Comités de seguimiento de estos Pactos ha dado lugar a toda una interpretación internacional, como ponen de relieve el Comentario General № 4 del Comité de Seguimiento del PIDESC sobre el derecho a una vivienda adecuada de 13 de diciembre de 1991, o el Comentario $n^{\circ} 7$ del Comité de seguimiento del PIDESC sobre el derecho a una vivienda adecuada y los desahucios forzosos, de 20 de mayo de 1997, en los que, entre otros extremos de trascendencia interpretativa para el legislador español, se afirma:

- la titularidad individual universal -y no solo familiar- de ese derecho;

- su extensión al carácter adecuado o digno de la vivienda en términos de intimidad, espacio, iluminación, ventilación, infraestructuras básicas y ubicación en relación con el puesto de trabajo, etc...;

- la necesidad de que existan garantías legales de protección para su disfrute en los términos indicados y a un coste razonable;

- el derecho a no ser desahuciado o desalojado (individual o colectivamente) de su vivienda a la fuerza sin el respeto del adecuado procedimiento y de unas determinadas garantías, legales. 
Ninguno de estos aspectos mencionados -reiterados en una línea semejante por la Decisión del Comité Europeo de Derechos sociales, de 5 de diciembre de 2007, Caso FEANTSA v. France, solo parcialmente vinculante para España al referirse a la Carta Social Europea revisada de 1996- depende de la disponibilidad de recursos materiales por parte de los Estados y por ello se puede ver vulnerado tanto por acción como por omisión de éstos.

Ahora bien, más allá de estas garantías, se puede decir con carácter general, tal y como reconoce el propio art. 2.1 del mencionado PIDSEC, que la eficacia obligatoria prestacional de estos derechos sociales, en especial del derecho a la vivienda adecuada, se reduce en el ámbito internacional a obligar a los Estados parte a "adoptar medidas, tanto por separado como mediante la asistencia y la cooperación internacionales, especialmente económicas y técnicas, hasta el máximo de los recursos de que disponga, para lograr progresivamente, por todos los medios apropiados, inclusive en particular la adopción de medidas legislativas, la plena efectividad de los derechos aquí reconocidos" (art. 2.1 PIDESC). En otras palabras, sin la intermediación del legislador o del Gobierno del Estado, no surge de esos instrumentos un derecho subjetivo prestacional, directamente invocable ante los tribunales, para que el Estado provea materialmente de una vivienda a quien no puede acceder a ella, pero sí surgen y forman parte del contenido esencial de este derecho social una serie de prohibiciones de discriminación, arbitrariedad, ilegalidad, y unas obligaciones normativas de protección de la propiedad o posesión de la vivienda, que son directamente invocables ante los tribunales en virtud de los respectivos instrumentos internacionales ligados al art. $47 \mathrm{CE}$.

\section{B) Garantía indirecta del derecho a la vivienda adecuada.}

Frente a los anteriores instrumentos internacionales que suponen una garantía directa, aunque modulable por el legislador nacional, de un derecho a una vivienda digna de titularidad universal, aparecen una serie de textos internacionales, que suponen una garantía indirecta del mencionado derecho, en la medida en que, presuponiendo el acceso a una vivienda introducen, con otras finalidades distintas, elementos que indirectamente garantizan la adecuación y la dignidad de la misma. Tal es el caso, por ejemplo del art. 17.1 del Pacto Internacional de Derechos Civiles y Políticos o del art. 8 del Convenio Europeo de Derechos Humanos que garantizan la vida privada y familiar y la inviolabilidad del domicilio, el derecho a no ser sometido a tratos inhumanos o degradantes (art. $3 \mathrm{CEDH}$ ), o el derecho al proceso debido (art. 6 CEDH). Así, cabe decir, ejemplificativamente, que el Tribunal Europeo de Derechos Humanos ha corroborado esta garantía indirecta internacional en diversas decisiones, en que las que ha vinculado diversas facultades integrantes del derecho a una vivienda adecuada con los derechos civiles antes mencionados.

Tal es el caso de la STEDH Moldovan y otros v. Rumanía, de 12 de julio de 2005, en la que se consideró que las condiciones habitacionales y la 
discriminación racial a las que las autoridades sometieron a los demandantes lesionaron su dignidad humana y su derecho a no recibir tratos inhumanos 0 degradantes; la STEDH López Ostra v. España, de 9 de diciembre de 1994, conforme a la cual se protege el derecho a la vivienda a través de la protección de la vida privada y familiar frente a la contaminación, humo y malos olores producidos por una planta de tratamiento de residuos, no prevenida ni eliminada por las autoridades públicas; o finalmente, la STEDH Connors v. Reino Unido, de 27 de mayo de 2004, en la que se sostuvo que el desalojo del demandante de su vivienda no había respetado las garantías del proceso debido al no aportar una justificación adecuada de tal injerencia en el hogar y la vida familiar.

También se incluyen dentro de esta garantía indirecta las Disposiciones, Declaraciones, Recomendaciones y Conclusiones de otros organismos y foros internacionales en las que se insta a la cooperación internacional para solucionar el problema de la vivienda de determinados grupos o asentamientos humanos o para conseguir la sostenibilidad medioambiental del desarrollo de asentamientos humanos, como por ejemplo, la Directiva 2003/109/CE del Consejo de la Unión Europea, de 25 de noviembre de 2003, conforme a cuyo art. 11.1.f) los nacionales de terceros estados (no comunitarios), en los que concurra la condición de ser residentes de larga duración en cualquier Estado miembro de la UE, deberán ser tratados igual que los nacionales en lo que se refiere al acceso a bienes y a servicios y el suministro de bienes y servicios a disposición del público, así como los procedimientos para acceder a la vivienda; la Declaración de Vancouver de 11 de junio de 1976; la Agenda Hábitat de 14 de junio de 1996; la Declaración de Estambul; las Resoluciones de la Asamblea General de la ONU 51/177 de 16 de diciembre de 1996 y 53/242 de 28 de julio de 1998; la Declaración del Milenio de 8 de septiembre de 2000; la Resolución 18/5 de la Comisión de Asentamientos Humanos, en la que se solicitó que se promoviera la fusión del Foro del Medio Ambiente con el Foro Internacional de la Pobreza, para mejor coordinar el apoyo internacional en la aplicación de la Agenda Hábitat.

E igualmente, dentro de este segundo grupo entraría la legislación de la Unión Europea que regula diversos aspectos relacionadas con la construcción, calidad y adecuación de las viviendas, como es el caso de la Directiva 2004/18/CE sobre contratos públicos de obras, suministros y servicios; la Directiva 89/106/CE de productos de construcción; la Recomendación relativa a la aplicación y uso de los Eurocódigos para obras de construcción y productos de construcción; o la Directiva 2002-91-CE de eficiencia energética de los edificios.

La eficacia indirecta de estos instrumentos en relación con la garantía del derecho a la vivienda adecuada se ha subrayado en diversos ámbitos, de entre los cuales, resultan especialmente destacables, por ejemplo, las conclusiones que sobre el marco legal ha establecido el Informe Final sobre el acceso a la vivienda elaborado en 2001 por el grupo de Especialistas del 
Consejo de Europa. Dicho informe hace un Ilamamiento a los Estados del Consejo -sean o no parte de la Carta Social Europea revisada- para desarrollar un marco legal completo que facilite a las categorías de personas desfavorecidas el acceso a la vivienda, para dar a todos los residentes los mecanismos legales necesarios para dotar de efectividad el derecho a la vivienda, para definir en su legislación el concepto de "vivienda adecuada", tomando en consideración su dimensión de derecho humano tal y como la establece la Agenda Hábitat, así como los medios económicos y los aspectos culturales de cada país, y para aplicar los estándares de una vivienda adecuada no sólo a la construcción de nuevas viviendas, sino también gradualmente a la renovación de las viviendas existentes.

En resumen, lejos de lo que pudiera pensarse, la existencia de un margen de actuación de los Estados para elegir y poner en práctica los medios materiales necesarios para facilitar el acceso de todas las personas a una vivienda digna no supone la total inexigibilidad del contenido de ese derecho, dado que ciertas garantías, como las de salubridad, habitabilidad y funcionalidad para la vida doméstica de una vivienda que pretenda ser calificada de adecuada, las garantías de igualdad y no discriminación en el acceso a la vivienda, a las concretas ayudas que al respecto se articulen legalmente, así como, finalmente, las garantías legales de conservación de la propiedad o la posesión de la vivienda son directamente exigibles por los ciudadanos y tutelables ante los tribunales.

\section{MODELOS COMPARADOS DE REGULACIÓN CONSTITUCIONAL DEL DERECHO A LA VIVIENDA DIGNA}

Más allá de la normativa internacional, algunos Estados signatarios, con el fin de dar cumplimiento a los tratados internacionales mencionados, establecen, disposiciones constitucionales sobre el derecho a una vivienda adecuada, indisponibles para los poderes públicos ordinarios (en especial para el legislador y para el poder ejecutivo), y en ocasiones también directamente disponibles para sus titulares.

En este sentido, la variedad de modelos constitucionales es notable. Va desde ordenamientos en los que el texto constitucional carece de mención alguna a un derecho o principio social de acceso a la vivienda digna, hasta ordenamientos que garantizan en el nivel constitucional nacional o regional un derecho subjetivo prestacional de algunos individuos a una vivienda digna, pasando por los que establecen un principio rector de la política social y económica que, como fin de Estado, obliga genéricamente a los poderes públicos a adoptar medidas para, en el marco de sus disponibilidades materiales, facilitar el acceso a una vivienda adecuada. Clasificándolos, cabe apreciar los siguientes modelos de regulación constitucional de este "derecho" a la vivienda digna: modelo de garantía como un derecho social fundamental; modelo de garantía como un fin del Estado/principio rector de la política social y económica, y modelo de garantía indirecta a través de otros derechos fundamentales o de otros bienes o $u$ objetivos de valor constitucional. 
Veamos cada uno de ellos con un poco más de detalle, ejemplificados a la luz de la regulación constitucional de algunos países.

\section{A) Modelo de garantía como un derecho social fundamental.}

Algunos textos constitucionales han creado la apariencia de un derecho subjetivo (fundamental) a la vivienda digna, mediante su reconocimiento expreso a los nacionales o a todas las personas. Sin embargo, no siempre este reconocimiento expreso es la manifestación de una garantía de un auténtico derecho fundamental a la vivienda, a pesar de que se utilice la expresión "todos tendrán derecho" o "los españoles tendrán derecho", sino que en muchas ocasiones, tras semejantes pomposas declaraciones, de forma explícita o implícita, en el mismo o en otros preceptos constitucionales, se rebaja el grado de eficacia obligatoria sobre los poderes públicos de dichas proclamas y el derecho queda reducido a un principio rector de la política social y económica o, lo que es lo mismo, a un mero fin que el Estado debe alcanzar. Por ello es necesaria una delimitación conceptual y textual de este modelo de garantía en el derecho comparado.

Es generalmente sabido en la doctrina y la jurisprudencia constitucional comparadas que para que la garantía del derecho a la vivienda sea un auténtico derecho social fundamental es preciso que el texto constitucional reconozca al individuo una facultad subjetiva para exigir una prestación material (derecho prestacional) o al menos una prestación normativa (garantía de organización y procedimiento), y en caso de no ser atendido acudir directamente ante los Tribunales sin intermediación de los poderes públicos. Y lo cierto es que ello no ha sucedido en la inmensa mayoría de los sistemas constitucionales que aparentemente se adscriben a este modelo, puesto que bien el propio texto constitucional expresamente, bien la interpretación que la jurisdicción constitucional ha hecho de los preceptos relativos al derecho a la vivienda, relativizan la eficacia vinculante del derecho y degradan a mero principio rector de la política social y económica. Tal es el caso, sin duda, de nuestro art. $47 \mathrm{CE}$, que crea esta confusión en relación con el derecho a la vivienda, al disponer literalmente, con expresiones propias de un derecho subjetivo, que:

"Todos los españoles tienen derecho a disfrutar de una vivienda digna y adecuada. Los poderes públicos promoverán las condiciones necesarias y establecerán las normas pertinentes para hacer efectivo este derecho, regulando la utilización del suelo de acuerdo con el interés general para impedir la especulación. La comunidad participará en las plusvalías que genere la acción urbanística de los entes públicos."

Y sin embargo, el art. 53.3 CE matiza la eficacia obligatoria de ese y del resto de los aparentes "derechos" reconocidos en el capítulo III de su Título I, reconduciéndolos a inspirar la legislación positiva y la práctica judicial, y a ser invocables ante los tribunales ordinario solo "en los términos que establezcan las leyes que los desarrollen", lo que excluye que nazca de ellos 
directamente y sin intermediación del legislador un poder individual para exigir de los poderes públicos una prestación material de vivienda.

Ejemplos similares de un falso derecho fundamental a la vivienda digna nos los ofrecen el art. 47 de la Constitución de Ucrania de 1996 o el art. 82 de la Constitución de Venezuela de 1999, en los que a renglón seguido de reconocer el derecho a la vivienda digna, implícitamente se circunscribe su eficacia obligatoria a la de un principio rector de la política social y económica, encomendando al Estado únicamente su satisfacción progresiva en el marco de las disponibilidades y recursos del Estado.

Lo mismo cabría pensar de las Constituciones de algunos Länder alemanes (art. 106 Const. Baviera o art. 28.1 Const. Berlín), en las que se reconoce explícitamente el derecho a acceder a una vivienda adecuada como un derecho fundamental. Sin embargo, precisamente en alguno de estos ordenamientos jurídicos se ha optado por reconocer como un auténtico derecho subjetivo de carácter social el derecho a la vivienda. Esta opción no resulta desconocida ni en el texto de la CE de 1978 ni en el derecho comparado respecto de otros derechos sociales, que reconocen, por ejemplo, el derecho a la educación (art. $27 \mathrm{CE}$ ) como un derecho fundamental de carácter social que confiere al individuo un poder para exigir de los poderes públicos la prestación gratuita de la educación básica obligatoria.

En efecto, volviendo al derecho a la vivienda adecuada y a su garantía directa como un derecho social de carácter fundamental, el art. 106 de la Constitución de Baviera establece que:

"1.- Todo habitante de Baviera tiene derecho a una vivienda adecuada. 2.- Es tarea del Estado federado y de los municipios el fomento de la construcción de viviendas sociales baratas".

Y el art. 28.1 de la Constitución de Berlín dispone que:

"Toda persona tiene derecho a una vivienda adecuada. El Estado promueve la adquisición y conservación de una vivienda adecuada, en especial para las personas de bajos ingresos, así como el acceso a la propiedad privada de las viviendas".

A pesar de que la doctrina y la jurisprudencia constitucional de dichos Estados federados se inclinan por minimizar el contenido de derecho subjetivo prestacional a la vivienda de dichos preceptos, reduciéndolos a un mero mandato de acción positiva que pesa sobre el Estado federado, lo cierto es que el Tribunal Constitucional del Estado de Berlín ha interpretado expresamente que el mencionado art. 28.1 de su Constitución garantiza también un derecho subjetivo prestacional a cargo del Estado en los supuestos de personas sin hogar (Decisión del Tribunal Constitucional de Berlín, Colección de Decisiones, Vol. 2, págs. 9-11; y Vol. 4, págs. 62-63). 
La titularidad de ese derecho fundamental, allí donde se ha garantizado es, como se puede ver, universal e independiente de la nacionalidad, lo que no impide que se puedan circunscribir las prestaciones únicamente a los individuos que reúnan una serie de condiciones objetivas de necesidad y/o incapacidad para acceder por sí mismos a una vivienda digna a través del mercado privado.

Por último, en los países escandinavos -de los que tomamos como modelo Finalndia- también se concibe la garantía constitucional de un derecho fundamental de carácter prestacional a la vivienda, que puede ser directamente exigido ante los tribunales. Así, el art. 19 de la Constitución de Finlandia dispone que:

“los poderes públicos promoverán el derecho a la vivienda de todas las personas y las oportunidades de acceder a su propia vivienda".

Los Tribunales contencioso-administrativo (Supreme Administrative Court, 1996 A45) han dado carta de derecho subjetivo a este derecho -al menos respecto de ciertos colectivos, como niños o discapaces) y han deducido del mismo la facultad de reclamar de los poderes públicos prestaciones básicas de carácter social en materia de vivienda.

En resumen, este primer modelo del derecho comparado, muestra cómo cabría recoger en España -previa reforma constitucional- un derecho fundamental a la vivienda digna del que se extrajesen prestaciones a cargo de los poderes públicos directamente invocables por los ciudadanos ante los tribunales.

B) Modelo de garantía como principio rector de la política social y económica.

Tal y como ya se ha apuntado anteriormente, la mayor parte de los ordenamientos constitucionales de nuestro entorno optan por garantizar el derecho a la vivienda digna, no como un auténtico derecho fundamental, sino como un principio rector de la política social y económica, bien sea recubierto solemnemente de una dicción propia de los derechos fundamentales pero contextualizado como un mero fin de Estado, o bien de forma ya directa y clara como un principio rector que orienta de forma jurídicamente vinculante la acción del Estado. El primero de los supuestos es, como ya se dijo, el del art. 47 de la CE, mientras que el segundo es el de diversas Constituciones nacionales y de algunos Länder alemanes. Así, por ejemplo, el art. 29.2 de la Constitución de Renania del Norte-Westfalia establece que:

\section{"Es competencia del Estado, conforme a lo dispuesto en las leyes, crear nuevas viviendas y locales de negocio y apoyar a los pequeños y medianos campesinos"}

y el art. 7 de la Constitución de Sajonia, expresamente intitulado "Existencia humana digna como fin de Estado", dispone que: 
"El Estado reconoce como un fin de Estado el derecho de toda persona a una existencia humana digna, en particular al trabajo, a una vivienda adecuada, a unos medios de vida adecuados, a la seguridad social y a la educación".

Ya en el terreno de las Constituciones nacionales hemos seleccionado como representativos de esta forma de garantizar el derecho a la vivienda a través de un principio rector de la política social y económica cuatro textos constitucionales correspondientes al constitucionalismo inmediatamente posterior a la segunda guerra mundial, al constitucionalismo escandinavo especialmente tuitivo en materia social-, al constitucionalismo postcomunista y al constitucionalismo de los años 70 del siglo $X X$, al que pertenece también la CE de 1978.

Comenzando por el constitucionalismo de posguerra, el art. 47 de la Constitución italiana dispone que:

"La República estimulará y protegerá el ahorro en todas sus formas; disciplinara y coordinara el ejercicio del crédito. Favorecerá el acceso del ahorro popular a la propiedad de la vivienda, a la propiedad agraria directa y a la inversión accionaria directa e indirecta en los grandes complejos productivos del país".

En el ámbito del constitucionalismo escandinavo, el art. 19 de la Constitución de Finlandia que dispone:

"Es tarea del poder público el fomentar el derecho de todos a la vivienda y apoyar las iniciativas privadas de vivienda".

Entre las Constituciones surgidas a partir de la caída del telón de acero, merece la pena reseñar el art. 75 de la Constitución de Polonia que establece que:

"1. Los poderes públicos perseguirán políticas dirigidas a satisfacer las necesidades de vivienda de los ciudadanos, en particular a combatir las situaciones de personas sin hogar, promoviendo el desarrollo de viviendas para bajos ingresos y apoyando las actividades orientadas a la adquisición de una vivienda por cada ciudadano. La Ley establecerá la protección de los derechos de los arrendatarios".

Pero de todos los documentos constitucionales encuadrables en este modelo, mayoritario como fórmula de garantía del derecho a la vivienda digna, destaca la Constitución de Portugal de 1976, cuyo art. 65, intitulado "Vivienda y urbanismo", es muy descriptivo del amplísimo contenido normativo que puede tener un derecho a la vivienda configurado como un principio rector de la política social y económica dirigido a los poderes públicos. En el se dispone: 
"1. Todos tienen derecho, para sí y para su familia, a una vivienda de dimensión adecuada, en condiciones de higiene y confort, y que preserve la intimidad personal y la privacidad familiar.

2. Para garantizar el derecho a la vivienda incumbe al Estado:

a) Programar y ejecutar una política de vivienda integrada en los planes generales de ordenación del territorio y apoyada en Planes de urbanismo que garanticen la existencia de una red adecuada de transportes y equipamientos sociales;

b) Promover, en colaboración con las regiones autónomas y con los entes locales, la construcción de viviendas económicas e sociales;

c) Estimular la construcción privada, con subordinación al interés general, y el acceso a la vivienda propia o arrendada;

d) Incentivar y apoyar las iniciativas de las comunidades locales y de las ciudades, tendentes a resolver los respectivos problemas habitacionales y a fomentar la creación de cooperativas de vivienda y de autoconstrucción.

3. El Estado adoptará una política tendente a establecer un sistema de renta de alquiler compatible con los ingresos familiares y el acceso a la vivienda propia.

4. El Estado, las regiones autónomas y los entes locales definen las reglas de ocupación, uso y transformación del suelo urbano, especialmente a través de los instrumentos de planeamiento, en el marco de las leyes relativas a la ordenación del territorio y el urbanismo, y proceden a la expropiación del suelo que se revele necesaria para la satisfacción del los fines de utilidad pública urbanística.

5. Y garantiza la participación de los interesados en la elaboración de los instrumentos de planeamiento urbanístico y de cualesquiera otros instrumentos de planeamiento físico del territorio".

Como se puede ver, en este modelo de garantía constitucional como principio rector, sea cual sea la fórmula textual de constitucionalización elegida, destacan tres características normativas esenciales:

a) Si dejamos a un lado la excepción de Polonia y de nuestro propio país, que circunscriben constitucionalmente la condición de beneficiarios del principio rector en materia de vivienda a los nacionales ("ciudadanos" y "españoles" respectivamente), la inmensa mayoría de los ordenamientos confieren al derecho/principio rector a una vivienda digna una titularidad universal, por lo que consideran que todas las personas que se encuentren en la situación de necesitar alguna de las acciones positivas de protección o ayuda que puede aportar el Estado para garantizar el acceso a una vivienda o la adecuación y dignidad de ésta son beneficiarias potenciales de dicho principio rector. En el concreto caso de nuestro ordenamiento, a pesar de la inicial circunscripción constitucional del derecho a la vivienda a los españoles, la acción conjunta del art. 13.1 CE, que permite a los extranjeros disfrutar también de los derechos que se deriven de los principios rectores que se 
encuentran en el Título I en los términos previstos en la Ley o los Tratados, y del derecho internacional y comunitario antes aludido, así como de lo dispuesto en el art. 13 de la Ley de extranjería, hace que los "extranjeros residentes" tengan derecho a acceder a las ayudas que en materia de vivienda puedan proveer los poderes públicos en las mismas condiciones que los españoles.

b) Por mucha eficacia obligatoria que pueda tener, lo cierto es que un principio rector de la política social o económica, como el relativo al derecho a la vivienda, no obliga a los poderes públicos a ninguna prestación o actividad concreta que de lugar a un cierto resultado material -ni podría hacerlo por otra parte, sin alterar el reparto constitucional de poderes entre el poder judicial y el poder legislativo/ejecutivo-, sino que únicamente obliga a establecer, en función de las políticas presupuestarias, unos medios materiales y/o normativos idóneos para alcanzar un rango de posibles resultados compatibles con la consecución de dicho fin estatal: el acceso de los titulares (todos o los nacionales) a una vivienda digna. De estos medios, los únicos que está obligado a establecer el legislador, incurriendo en inconstitucionalidad por omisión en caso de no hacerlo, son los de carácter normativo, es decir, un marco legal que garantice la dignidad de la vivienda a la que accedan los individuos y la no desposesión de la misma al margen del debido proceso legal, o de una forma discriminatoria o arbitraria, en correspondencia con lo establecido por el Comité de seguimiento del Pacto de Derechos Económicos sociales y culturales con respecto al art. 11 de dicho Pacto, dada la eficacia jurídica vinculante del mismo como criterio interpretativo del alcance obligatorio del art. 47 CE y como fuente de derechos subjetivos de carácter legal internacional (art. $96 \mathrm{CE}$ ).

c) El conjunto de medios materiales y/o normativos a través de los cuales los poderes públicos de cada Estado pueden dar cumplimiento al contenido finalista del derecho a la vivienda digna es lo suficientemente amplio, como demuestra el art. 65 de la Constitución portuguesa, como para que sean objeto de una concreción en las leyes de desarrollo de dicho principio rector, sobre todo si, como es el caso del art. $47 \mathrm{CE}$, el tenor literal del precepto constitucional es mucho menos explícito en relación con los instrumentos a través de los cuales se satisface el "derecho" a la vivienda digna. Y pueden ir desde la provisión directa por parte del poder público de alojamiento temporal para quien se encuentra totalmente incapacitado para acceder por sí mismo en el mercado a una vivienda digna (alojamientos sociales para los denominados "sin techo") hasta la simple regulación pública del mercado inmobiliario privado -tanto de compraventa como de alquiler- de modo que las condiciones de acceso sean lo suficientemente variadas como para que cualquiera pueda acceder a uno $u$ otro tipo de vivienda digna, pasando, por supuesto, por intervención directa del Estado en el mercado inmobiliario mediante la reserva de suelo y/o la venta de viviendas de promoción pública, o las ayudas públicas a la compra o al alquiler para individuos con ingresos limitados.

DiReITOS FundamentaIS $\mathcal{E}$ JUSTIÇA N 14 - JAN./MAR. 2011 
Ninguno de estos medios viene impuesto constitucionalmente y entran todos dentro de las políticas de vivienda que la mayoría política gobernante quiera poner en práctica en cada momento a corto, medio o largo plazo.

C) Modelo de garantía indirecta a través de otros derechos fundamentales o bienes de rango constitucional.

En los sistemas constitucionales presididos por este tercer modelo de garantía del derecho a la vivienda digna no se recoge textualmente un derecho social fundamental ni tampoco un principio rector en materia de acceso a la vivienda digna. El silencio constitucional, sin embargo, no puede ser visto como una total ausencia de compromiso con dicho valor social, sino que en muchas ocasiones su garantía opera de forma indirecta a través de la protección de otros derechos fundamentales, o a través de su vinculación a un bien o valor de rango constitucional como la dignidad de la persona, la inviolabilidad del domicilio, la intimidad, el secreto de las comunicaciones, pero también integridad física y moral, o la salud.

Aunque en principio el legislador que desarrolle estos bienes o principios de valor constitucional podría circunscribir la titularidad de todas o de algunas de las prestaciones estatales a un colectivo reducido de personas, la influencia del derecho internacional al que antes se hizo alusión y la propia naturaleza universalista de dichos principios, vinculados habitualmente a la dignidad de la persona, así como a derechos fundamentales de titularidad universal, hacen que bajo este modelo normalmente no se exija la nacionalidad a los titulares de las prestaciones o ayudas que conforman este "derecho a la vivienda digna", y que, de existir circunscripciones subjetivas del colectivo de beneficiarios, éstas vengan determinadas por circunstancias objetivas vinculadas a la razón de ser de la garantía de esta expectativa, como la residencia de los beneficiarios en el ámbito territorial de la entidad que las concede, o sus necesidades y su potencial capacidad para proveerse por sí mismos de una vivienda digna en el mercado privado.

Un primer ordenamiento ejemplificativo de este modelo es el francés, en el cual el Consejo Constitucional, en diversas decisiones (entre otras, la Decisión 94-359 de 1995) ha vinculado el derecho a una vivienda digna con uno de los objetivos de valor constitucional establecidos en el Preámbulo de la Constitución de 1946, al que sigue dando vigencia el texto de la vigente Constitución de 1958. El Consejo deduce esta consecuencia del citado Preámbulo de la Constitución de 1946, que, si bien no hace referencia alguna a este derecho, sí afirma en sus apartados 10 y 11 que "la Nación asegura al individuo y a la familia las condiciones necesarias para su desarrollo", así como que "garantiza a todos, especialmente al niño, a la madre y a los viejos trabajadores, la protección de la salud, la seguridad material, el descanso y el ocio".

Además, el mismo Preámbulo subraya que "la salvaguarda de la dignidad de la persona humana contra toda forma de degradación es un principio de 
valor constitucional" y que "todo ser humano, incapaz de trabajar por razón de su edad, estado físico o mental o situación económica, tiene el derecho de obtener de la colectividad medios convenientes de existencia". Este nuevo objetivo de valor constitucional, que se deriva de tales principios, incumbe, según el Consejo Constitucional, tanto al Legislador como al Gobierno, que habrán de determinar, conforme a sus competencias respectivas, "las modalidades de su puesta en práctica", hasta el punto, como recuerda la Decisión 98-403 DC, de 29 de julio de 1998, de poder incluso llegar a limitar la libertad individual y el derecho a la propiedad, siempre que tales limitaciones no alcancen una gravedad que desnaturalicen el sentido y alcance de esos derechos. El derecho a la vivienda adecuada no tiene, pues, en Francia la consideración de derecho fundamental, ni de un principio ni de una regla de valor constitucional, sino solo un objetivo de valor constitucional que opera de forma relativamente parecida pero más laxa que los fines de Estado del modelo anterior, marcando a los poderes públicos una pauta a seguir en su actuación en dicha materia, pero sin generar por sí mismo ninguna pretensión subjetiva directamente invocable ante los Tribunales.

Un segundo ejemplo de esta garantía indirecta lo ofrece la Ley Fundamental de Bonn alemana, que expresamente no ha garantizado el derecho a la vivienda digna ni como un derecho social, ni como un principio rector de la política social y económica, y que se ha negado en diversos intentos frustrados de reforma constitucional a acoger semejante derecho en cualquiera de las dos anteriores formulaciones o modelos de garantía. Con todo, cabe reconducir su garantía, tal y como ha hecho el Tribunal Constitucional federal, a la obligación positiva que pesa sobre el Estado de garantizar unas condiciones mínimas necesarias para una existencia digna de la persona (art. 1.1. GG) en cumplimiento del principio de Estado social (art. 20.1 GG), condiciones de las que forman parte sin duda la posesión de una vivienda adecuada y suficiente, cuyo acceso el Estado está obligado a posibilitar normativa y materialmente, pero sin que se haya derivado de uno $u$ otro precepto un derecho subjetivo del individuo a exigir semejante prestación.

También se ha reconducido en la jurisprudencia del Bundesverfassungsgericht alemán la garantía del derecho a una vivienda digna a la garantía de otros derechos como la inviolabilidad del domicilio (art. $13.1 \mathrm{GG}$ ) o el derecho de propiedad (art. 14 GG), que indirectamente sirven a la preservación de algunos aspectos de la dignidad del espacio en el que se desarrolla la vida en una vivienda digna, tales como la expectativa de no ser perturbado por el poder público -y de ser protegido por éste- dentro del espacio domiciliario en el que se desarrolla la vida privada del individuo (BVerfGE 109, 279 - Großer Lauschangriff), la tutela jurídica del poder de rescisión del contrato de arrendamiento de una vivienda para su propio disfrute por el propietario o sus familiares más próximos (BVerfGE 79, 292 Eigenbedarf II), y simultáneamente también la tutela jurídica del vínculo jurídico arrendaticio que posee el arrendatario de una vivienda frente a 
rescisiones no basadas en la propia necesidad de ocupación por el propietario, sobre la base de la necesaria función social de la propiedad (BVerfGE 68, 361 - Eigenbedarf I).

\section{MODELOS COMPARADOS DE DESARROLLO LEGAL DEL DERECHO A LA VIVIENDA DIGNA.}

La enorme diversidad de fórmulas que el legislador ha utilizado en los Estados de nuestro entorno a la hora de dar cumplimiento a los mandatos constitucionales y/o internacionales que le conminaban a adoptar medidas que permitan el acceso a una vivienda digna al mayor número de personas posible, hace muy difícil tomar como referencia las experiencias del derecho comparado -aunque sea necesario-, sin antes hacer una clasificación, por simplificadora que esta sea, de las diversas experiencias normativas en la materia. Para clasificarlas hemos creído oportuno utilizar como principales criterios los dos siguientes: el número y tipo de instrumento normativo en el que se desarrolla el derecho a la vivienda, y sobre todo que se reconozca o no un derecho a la vivienda como un derecho prestacional genérico, judicialmente exigible, para que las autoridades estatales provean de una vivienda a quien carece y no está en condiciones de acceder a ella, al margen de los concretos derechos de acceso a específicas prestaciones en materia de vivienda (como ayudas para sufragar los costes de la vivienda, préstamos subvencionados, ayudas a la construcción y/o adquisición, etc...).

De la aplicación estos dos criterios resultan tres modelos normativos combinables entre sí- en los que cabe enmarcar la mayor parte de los ordenamientos europeos. El primero es el modelo germánico, conforme al cual se tiende a regular en grandes leyes integrales todo lo relativo a los dos principales aspectos garantizados por el derecho a la vivienda digna: la dignidad o adecuación de la vivienda a través de legislación sobre el suelo y la edificación, y las prestaciones materiales o normativas que facilitan el acceso a la vivienda a través de legislación sobre el fomento de la vivienda a determinados colectivos desfavorecidos y las ayudas económicas para hacer frente a los gastos de vivienda, pero sin concebirlas en ningún caso como derechos subjetivos. El segundo modelo, del que es genuino representante Francia, se ha arriesgado a garantizar con carácter general, como derecho prestacional judicialmente exigible, el derecho de todo individuo que lo necesite a acceder a una vivienda adecuada, aunque las previsibles dificultades financieras para hacerlo efectivo ya le llevaran a prever en el texto de la Ley una serie de condicionamientos temporales y prelaciones subjetivas para su ejercicio. El tercer y último modelo regulatorio se da curiosamente, en aquellos Estados con mayor capacidad económica per capita y mayor efectividad a la hora de satisfacer este mandato social que pesa sobre los poderes públicos, los países escandinavos, que optan por desmenuzar legislativamente en una pluralidad de normas y para una diversidad de individuos, sometidos a diferentes requisitos, las distintas ayudas estatales que se establecen para acceder y/o disfrutar de una vivienda adecuada. 
Sin ánimo de realizar un análisis exhaustivo ni pormenorizado de la regulación del derecho a la vivienda en cada uno de estos modelos, veamos con un poco más detalle algunos aspectos concretos característicos de ellos.

A) Modelo germánico: las leyes integrales de edificación y de promoción del acceso a la vivienda.

La legislación alemana sobre vivienda se construye a partir de dos grandes bloques de legislación federal, que constituyen el marco en el que los Estados federados y los entes locales deben desarrollar y ejecutar sus diversas políticas de vivienda: un primer bloque es el constituido por las normas que inciden sobre la adecuación o dignidad de la vivienda y está constituido coordinadamente por la Ley de ordenación del suelo (Raumordnungsgesetz), el Código de la edificación (Baugesetzbuch) y el Reglamento de edificación de cada Estado federado (Bauordnung), mientras que el segundo bloque afecta a la acción positiva que el Estado ha de desempeñar para facilitar a los ciudadanos el acceso y disfrute de una vivienda y está formado por la Ley de promoción (social) de la vivienda (Wohnraumförderungsgesetz) y la Ley de ayudas económicas a la vivienda (Wohngeldgesetz).

En ambos bloques se trata de leyes que pretenden regular de forma integral y separada, como un marco mínimo, tanto las condiciones de la edificación, incluida la destinada a vivienda, como los concretos instrumentos de los que los poderes públicos se pueden servir para facilitar el acceso y disfrute de una vivienda. Estos últimos van desde el reconocimiento de concretos derechos subjetivos a una ayuda económica para costear el alquiler o los gastos de disfrute de la vivienda, en proporción a sus ingresos y al coste del alquiler/hipoteca, hasta las ayudas estatales para el acceso a la vivienda social a través de la construcción de vivienda pública, la reserva de suelo para dicha construcción o el acceso a una vivienda de protección oficial. Con estas medidas, los individuos deben encontrarse en condiciones de acceder a una vivienda proporcionada por el mercado privado o por el mercado público, rigiendo en todo lo no previsto por estas leyes las disposiciones generales de carácter civil relativas al contrato de alquiler o al derecho de propiedad.

Por lo que respecta a la acción pública en materia de acceso a la vivienda, la legislación alemana distingue entre las medidas de fomento social del acceso a la vivienda y las medidas de ayuda económica para el disfrute de una vivienda adecuada. Para atender al acceso a la vivienda, la ley de promoción (social) de la vivienda, sucesora de la segunda ley de construcción de viviendas sociales, prevé el fomento de la construcción de vivienda social y de otras medidas de apoyo al alquiler, la adquisición cooperativa o la propia construcción de vivienda por parte de las unidades familiares de bajos ingresos que no pueden proveerse adecuadamente de vivienda en el mercado privado.

La ley prevé que los Estados federados diseñen, en conjunción con los municipios, programas de promoción social de la vivienda por los que se financie la construcción o adquisición de vivienda, su modernización y la 
adquisición de derechos de ocupación (fundamentalmente a través del alquiler) de viviendas preexistentes, y que todo ello se haga a través de una financiación pública que puede consistir tanto en préstamos públicos en condiciones preferenciales, préstamos garantizados o subvenciones a fondo perdido, como en la asunción de garantías inmobiliarias, pasando por el ofrecimiento de suelo urbanizable a precios moderados.

Aunque se habilita a los Estados federados para concretar las condiciones de la promoción de la vivienda, establecidas por la Ley, ella misma ya establece unos principios generales conforme a los que debe operar la promoción y que operan como estándares mínimos que los Estados pueden mejorar pero nunca empeorar. Entre ellos se encuentran una serie de límites a los costes de alquiler que pueden tener las viviendas objeto de promoción para facilitar "derechos a su ocupación", la preferencia de familias con al menos dos hijos o personas discapacitadas a su cargo respecto de la promoción de la construcción de vivienda propia, la exigencia de un tamaño proporcionadamente limitado de las viviendas a financiar, así como unos límites de ingresos anuales de las unidades familiares beneficiarias de las medidas de promoción.

Los beneficiarios de las medidas de promoción no siempre coinciden con los receptores de las ayudas, puesto que, según la ley, estos últimos son: los promotores de viviendas de nueva construcción, los adquirentes de una vivienda construida para propio uso individual o colectivo (cooperativas), o los propietarios-inversores en el caso de la adquisición de derechos de ocupación (alquiler).

De todos modos, y con independencia de la concreta regulación de cada una de estas medidas de fomento detalladas en la Ley federal, y en las Leyes y programas de los distintos Estados federados, lo característico de este modelo -por contraste con lo que luego se dirá en relación con el modelo francés- es que las propias disposiciones legales tanto federales como estatales expresamente afirman que de las mismas no surge ningún derecho subjetivo a percibir las ayudas promocionales en ninguna de las modalidades previstas. Se trata pues de una concesión administrativa que adopta la forma de un acto administrativo o un contrato público al que ni siquiera se tiene derecho ex lege, sino a partir de las concretas bases reglamentarias de concesión que figuren en el programa o plan de vivienda de cada Estado federado.

Por su parte, en relación con el otro bloque de medidas, la Ley de ayudas económicas a la vivienda (Wohngeldgesetz) contempla, con la finalidad de asegurar económicamente el disfrute de una vivienda adecuada y familiar, unas subvenciones públicas al alquiler o a las cargas inmobiliarias en beneficio de los arrendatarios y de los propietarios de viviendas (nacionales y extranjeros residentes o ciudadanos de la UE).

La concreta cuantía de estas ayudas se predetermina legalmente ad personam en función de tres criterios: el número de miembros de la unidad 
domiciliaria, la cuantía del alquiler o de las cargas (dentro de los que se incluyen además del importe de la renta, el de los gastos de suministros de agua, luz y calefacción, así como el importe del capital y los intereses tomados en préstamo para la adquisición de la vivienda) y los ingresos totales netos de la unidad domiliciaria para la que se solicita la subvención (calculados conforme a una serie de criterios que también incluyen partidas de ingresos exentas de tributación por el Impuesto sobre la Renta de las Personas Físicas). Se trata de un derecho subjetivo a la subvención del que sólo se excluye a quienes reciban una serie de ayudas sociales y pensiones previstas con carácter de mínimo vital por la legislación de la seguridad social (Sozialgesetzbuch), siempre, eso sí, que las mismas incluyan cuantías para hacer frente a los gastos de vivienda, así como a quienes estén cumpliendo el servicio militar obligatorio (durante ese período de tiempo), a quienes estén percibiendo ayudas al estudio que ya incluyen el concepto de vivienda, o a quienes posean por otras fuentes un patrimonio destacado que haga abusiva la percepción de la subvención.

Fruto de la aplicación de los citados criterios la Ley prevé una fórmula matemática en virtud de la cual es posible calcular la concreta cuantía de subvención para la vivienda que corresponde a cada solicitante: 1,08€. $(M-(a+b \cdot M+c \cdot Y) \cdot Y)$, donde $M$ es la cuantía redondeada mensual del alquiler o la carga inmobiliaria a sufragar, $Y$ es la cuantía mensual redondeada de ingresos totales y a, b y c son valores fijos y diferentes previstos en un anexo a la Ley en función del número de miembros de la unidad familiar. La propia Ley contempla que si la cuantía que se deriva de la aplicación de dicha fórmula es inferior a 10 euros mensuales no se genere el derecho a la subvención.

B) Modelo francés: la garantía legal de un derecho a la vivienda judicialmente exigible.

El camino recorrido por la legislación francesa hasta la garantía de un derecho prestacional a la vivienda, judicialmente exigible, comenzó con la Ley 90-449, de 31 de mayo de 1990, aún vigente, en virtud de la cual "toda persona o familia que sufra dificultades particulares, en razón especialmente de la inadaptación de sus recursos o de sus condiciones de existencia, tiene derecho a una ayuda de la colectividad, en las condiciones fijadas en la Ley, para acceder a una vivienda digna e independiente, mantenerse allí y disponer en ella de suministro de agua, energía y servicios telefónicos".

Lo primero que es preciso aclarar, es que, si bien esta Ley no define expresamente cuando una vivienda es digna, sensu contrario contribuye a esa definición cuando califica de indignos los locales e instalaciones que, usados como vivienda, resultan impropios por su naturaleza para ese uso, y a las así como las viviendas cuyo estado o el del edificio en el que se ubican exponen a sus ocupantes a riesgos para su salud o su seguridad.

En segundo lugar, cabe decir, que las medidas destinadas a permitir el acceso a una vivienda digna y al suministro indicado serán objeto en cada 
Departamento de un "Plan departamental de acción para la vivienda de las personas desfavorecidas", que incluirá el Plan de acogida, alojamiento e inserción de personas sin domicilio, ya previsto en el Código de acción social y de las familias. A fin de asegurar la puesta a disposición de un alojamiento duradero, el Plan tiene que definir una serie de medidas concernientes al seguimiento de las peticiones de vivienda, la creación de una oferta suplementaria de viviendas, la coordinación de la atribución prioritaria de viviendas, la prevención de desahucios de inquilinos, la ubicación de personas en alojamientos temporales o de transición, la localización de viviendas indignas, la estrategia sobre movilización de viviendas en el parque privado o la contribución a los fondos de solidaridad para la vivienda.

Estos fondos, creados en cada Departamento y financiados sustancialmente, aunque no únicamente por él, acuerdan concretas ayudas financieras bajo forma de cauciones, préstamos o adelantos reembolsables, garantías o subvenciones a las personas que se encuentran en las condiciones citadas y que acceden a un alojamiento en alquiler; a las que, siendo ya arrendatarias, subarrendatarias o residentes en viviendas-hogar, les es imposible asumir las obligaciones relativas al pago del alquiler, cargas y gastos del seguro de vivienda; o a las que, ocupando regularmente su vivienda, no pueden asumir el pago de los suministros de agua, energía y teléfono; distribuyéndose todas las ayudas en función del nivel de patrimonio y recursos de las personas, y de la importancia y la naturaleza de sus dificultades, sin que puedan ser sometidas a ninguna condición de residencia previa en el Departamento.

El fondo de solidaridad también concede ayudas a propietarios que ocupan su vivienda cuando están en la situación de necesidad mencionada; cuando no pueden asumir el pago de las cargas colectivas si su vivienda está situada en un grupo de inmuebles en obras o es objeto de un plan de salvaguarda; cuando no pueden reembolsar préstamos contratados para la adquisición de la vivienda; o cuando, encontrándose en las situaciones anteriores, el inmueble está situado en el perímetro de una operación programada de mejora del hábitat.

De todo lo dicho parece claro que esta Ley de 1990 se limita tan sólo a reconocer el derecho a unas ayudas concretadas reglamentariamente, de forma similar a lo previsto las leyes integrales del modelo germánico o en la pluralidad de leyes del modelo anglo-escandinavo, lo que no es poco en comparación con lo anterior, pero no establece un derecho subjetivo prestacional genérico de acceso a la vivienda. No será hasta la Ley 2007-290, de 5 de marzo de 2007, cuando se cambie el modelo de garantía al disponerse en ella que el Estado garantiza el derecho a una vivienda digna e independiente, ya mencionado en la citada Ley $\mathrm{n}^{\circ}$ 90-449, a toda persona que residiendo en territorio francés de modo regular y en las condiciones de permanencia definidas por Decreto del Consejo de Estado - desde al menos dos años- no esté en situación de acceder a ella y mantenerse por sus propios medios. 
Y sobre todo, al añadir que este derecho se ejerce a través de un recurso amistoso y llegado el caso a través de un recurso contencioso y se exige frente al Estado, como responsable de la solidaridad nacional, sin perjuicio de que en el desarrollo de esa tarea estén llamados a colaborar otros entes territoriales e incluso las personas físicas o jurídicas privadas. Obviamente el acceso de los desfavorecidos a la vivienda, igual que el alojamiento de los más desprotegidos, depende de una política activa de construcción de viviendas sociales y de estructuras temporales de acogida. Esta política de ayudas, que se concreta en el Código de la edificación y la vivienda, tiende a favorecer una oferta de viviendas que por su importancia, su inserción urbana, su diversidad de estatutos de ocupación y su repartición espacial ha de asegurar la libertad de elección por las personas de su modo de alojamiento.

Por lo que se refiere a las políticas de construcción o puesta a disposición de viviendas sociales, entendiendo por tales las destinadas por iniciativa pública o privada a personas de bajos ingresos con dificultades para acceder al mercado libre, se distingue entre viviendas de alquiler moderado, construidas y administradas por un organismo público o privado que se benefician de exenciones fiscales y ayudas estatales por el servicio de interés general que prestan; viviendas subvencionadas o acordadas, construidas y administradas por personas privados; así como cooperativas de viviendas, cuya formación la subvencionan los poderes públicos. El Código también instituye ayudas personalizadas a la vivienda, siempre que sea residencia principal. Sus beneficiarios serán nacionales franceses y extranjeros en las condiciones previstas por los dos primeros párrafos del Código de la Seguridad social residentes que tengan a su cargo uno o más niños igualmente residentes en Francia, salvo trabajadores que están temporalmente para ejercer una actividad profesional y se encuentran exentos de afiliación a la seguridad social francesa-.

Pues bien, tras la reforma operada por la citada Ley de 2007, el Código de la edificación y la vivienda contempla, un programa preciso, escalado en el tiempo y de seguimiento regular, en el que las figuras de oferta de vivienda estable y oferta de acogimiento temporal se someten a un procedimiento similar de atribución para toda persona o familia con dificultades particulares para acceder y conservar una vivienda digna e independiente, en razón sobre todo de la inadaptación de sus recursos o de sus condiciones de existencia. Este derecho subjetivo, sin embargo, no es inmediatamente exigible ante los Tribunales, pues primero hay que intentar un procedimiento "amistoso" que, en caso de no llegar a buen término, permite abrir la fase contenciosa ante la jurisdicción contencioso-administrativa.

En el procedimiento amistoso interviene necesariamente una Comisión departamental de mediación ante la que pueden invocar este derecho y presentar su solicitud desde la entrada en vigor de la ley las personas pertenecientes a colectivos desfavorecidos, calificados de prioritarios, esto es, las personas desprovistas de vivienda, las amenazadas de expulsión sin 
realojo, los alojados temporalmente en un establecimiento de transición, los alojados en locales impropios a este fin, insalubres o peligrosos, los alojados en locales sobreocupados o considerados indignos si al menos tiene a su cargo un menor, un discapaz o ellos mismos presentan discapacidad o los que, cumpliendo las condiciones administrativas de acceso a una vivienda de alquiler social, no han recibido ninguna propuesta adaptada a su demanda en un plazo extremadamente largo.

La Comisión de mediación es la que motivadamente ha de seleccionar a las personas a las que prioritariamente se les debe atribuir una vivienda con urgencia y determinar las características de esta vivienda en función de sus necesidades, siendo el representante del Estado en el Departamento, previo dictamen de los Alcaldes de los municipios afectados, el que provee la misma. Cuando no se llega a dar satisfacción a la solicitud de una persona reconocida como prioritaria por la Comisión de mediación o a la solicitud de ser acogida en un centro de alojamiento, vivienda transitoria, vivienda tutelada o residencia hotelera con vocación social, cabe interponer recurso contencioso-administrativo ante los tribunales, que podrán ordenar el alojamiento o el realojo de del afectado y, en su caso, además una multa. El acceso a este recurso está, sin embargo, sometido a límites temporales, pues en una primera etapa, desde enero de 2008 hasta el 31 de diciembre de 2011 , solo es accesible a las personas más desfavorecidas, calificadas de prioritarias por la Ley, mientras que a partir de enero de 2012 podrá ser interpuesto por cualquier persona que cumpla las condiciones de acceso a viviendas de alquiler social y no haya recibido ninguna respuesta adaptada a su petición.

C) Modelo escandinavo: pluralidad de leyes de garantía de diversas prestaciones en materia de vivienda.

Este modelo se caracteriza por la dispersión normativa de las garantías del derecho a vivienda digna, que dan desarrollo al derecho social fundamental a la vivienda digna en diversos instrumentos legales contenedores de concretos derechos subjetivos de naturaleza prestacional y no reconducibles a unidad en leyes integrales por bloques o materias. Como prototipo de este modelo escandinavo tomaremos el ordenamiento finlandés, cuyas características están presentes con una estructura y unas denominaciones legislativas muy similares en los ordenamientos sueco y noruego.

Si dejamos a un lado tanto la normativa urbanística que garantiza la adecuación o dignidad de la construcción de viviendas, como las subvenciones de vivienda previstas para colectivos concretos -como estudiantes 0 pensionistas- que tienen su regulación específica, podremos ver cómo la regulación de las prestaciones en materia de vivienda se encuentra recogida en diversas leyes singulares entres las que están: la Ley de construcción de viviendas sociales (Housing Production Act), la Ley del Fondo de vivienda de Finlandia (Act on the Housing Fund of Finland), la Ley de préstamos de vivienda subvencionados estatalmente (Act on State-subsidized housing loans), 
la Ley de avales estatales a los préstamos de vivienda en propiedad (Act on State Guarantees for Owner-Occupied Housing Loans), la Ley de subvenciones estatales al interés de préstamos de vivienda en propiedad (Act on interest subsidy for owner-occupied housing loans) y la Ley de subvenciones estatales al interés de prestamos de vivienda para alquiler (Act on interest subsidy for rental housing loans), la Ley del derecho de ocupación de una vivienda (Right of occupancy housing Act), y finalmente la Ley de ayudas de vivienda (Housing allowance Act).

Con carácter general, se puede decir que las características diferenciales de este modelo regulatorio son: de un lado, por comparación con el modelo alemán, el que las distintas actuaciones públicas en materia de vivienda se regulan en una pluralidad de normas legales que individualmente se ocupan de cada ámbito de actuación (préstamos, ayudas económicas, adjudicación de viviendas sociales en alquiler, construcción de viviendas sociales, etc...) y se articulan como derechos subjetivos prestacionales en todos los casos incluidas las ayudas al acceso a la vivienda mediante préstamos a la construcción o el alquiler de viviendas sociales- aunque estén sometidos a múltiples condiciones suspensivas cuya concreción corresponde al Gobierno nacional. Y de otro lado, en comparación con el modelo francés, tanto la diversificación en una pluralidad de derechos subjetivos a obtener diferentes ayudas en materia de vivienda, como su subordinación legal a la fijación por parte del Gobierno de techos máximos de ingresos o cantidades mínimas financiables como condiciones suspensivas que forman parte de su supuesto de hecho, hacen de los mismos altamente realistas y practicables en función de las disponibilidades presupuestarias y la población potencialmente solicitante de los mismos, mucho más que un genérico derecho prestacional a la vivienda. Pero veamos esta regulación de estos concretos derechos prestacionales en materia de vivienda con un poco de detalle.

La Ley del fondo de vivienda de Finlandia de 1989, regula la existencia de un fondo económico del que se extraen las cantidades necesarias para los préstamos estatales de vivienda y para otras medidas de financiación de la vivienda, tal y como se prevea en otras disposiciones legales separadas. El Fondo lo componen, además de las aportaciones públicas de los presupuestos generales del Estado -sean genéricas o vinculadas a concretas ayudas y préstamos a la vivienda legalmente previstos-, las cantidades recibidas de la amortización e intereses pagados por los préstamos públicos de vivienda concedidos con cargo al propio fondo. Está gestionado como un organismo público autónomo por un consejo de administración y puede verse sometido anualmente a directrices presupuestarias emanadas del Parlamento.

Una de las principales aplicaciones de los medios económicos disponibles en el mencionado fondo de vivienda son los préstamos de vivienda subvencionados estatalmente (ARAVA), previstos por una Ley de 1993, que se otorgan para la construcción, la compra o la renovación de una vivienda en propiedad, alquilada o sometida a un régimen de derechos de ocupación. 
Los préstamos se conceden para la mejora de las condiciones de acceso a la vivienda en función de la adecuación social y de la necesidad financiera y sólo pueden referirse a viviendas que sean adecuadas en términos de habitabilidad, funcionalidad medioambiental, proporcionalidad de los costes de construcción, adquisición o renovación y sostenibilidad de los costes de mantenimiento.

En cualquier caso, los beneficiarios de los préstamos, que en el caso de la construcción, adquisición o renovación de vivienda propia pueden ser personas individuales, inmobiliarias promotoras o empresas propietarias de edificios para sus empleados (en este último caso para su renovación), y en el caso de la construcción, adquisición o renovación de viviendas para alquiler o para cesión de derechos de ocupación pueden ser entes locales y otros entes públicos, sociedades privadas de promoción de arrendamientos o viviendas sociales, así como de seguros, deben ser considerados potencialmente solventes para la devolución del préstamo. Las condiciones concretas para su solicitud, en función de cada tipo de actuación de vivienda financiada, vienen establecidas por la Ley citada y por el Reglamento de desarrollo de ésta.

En todo caso, la Ley dispone que su concesión compete, como regla general, a las autoridades locales cuando el solicitante es una persona privada individual y al Fondo de vivienda de Finlandia cuando se trata de sociedades privadas o de solicitantes que son entes públicos. También dispone que, como tal derecho subjetivo, es tutelable por la jurisdicción contenciosoadministrativa -una vez agotada la vía administrativa-. El importe del préstamo puede alcanzar como máximo el $80 \%$, el $95 \%$ o el $90 \%$ del valor objeto del préstamo en función de que la construcción, adquisición o renovación sea para ocupar la vivienda en propiedad, para su alquiler o para la concesión de derechos de ocupación respectivamente, y en ningún caso puede superar, computado con cualquier otro préstamo privado que pueda tener el solicitante respecto de la misma vivienda, entre el $90 \%$ y $95 \%$ del valor del inmueble objeto del préstamo de vivienda, dependiendo del tipo de préstamo.

Relacionados con estos préstamos de vivienda estatalmente subvencionados se encuentran los avales estatales a los préstamos de vivienda en propiedad previstos previstos por una Ley de 1996, y las ayudas estatales a los intereses de los préstamos de vivienda en propiedad y para oferta en alquiler, previstos respectivamente por Leyes de 1993 y 1980.

Por lo que se refiere a los avales, dentro de un número máximo fijado anualmente en los presupuestos generales del Estado, los concede el Fondo de vivienda de Finlandia a las personas físicas que contraigan con una entidad crediticia privada, una compañía de seguros o una entidad de previsión social un préstamo de hasta un máximo del 85\% del precio de compra o de construcción de su vivienda propia en Finlandia. Las decisiones del Fondo sobre esta materia pueden ser impugnadas ante la jurisdicción contenciosoadministrativa provincial, sin que quepa ulterior recurso. El aval cubre hasta un máximo del $20 \%$ del principal del préstamo restante por pagar durante 
toda la vida del mismo, y su concesión conlleva para el prestatario la obligación de abono al Estado a través de la entidad crediticia de una tasa del 1,5\% de la cuantía contraída por el aval estatal.

Por lo que respecta a las ayudas estatales para el pago de los intereses de los préstamos de vivienda en propiedad y para su oferta en alquiler, los créditos subvencionables han de ser concedidos por entidades crediticias privadas a personas físicas o jurídicas (privadas) de las que menciona la Ley de préstamos de vivienda estatalmente subvencionados, y de no ser utilizadas como vivienda propia, deben ser puestas en alquiler por un período que va de 10 a 20 años, dependiendo del plazo de amortización previsto para el préstamo. El tesoro público finlandés paga directamente el total de los intereses de tales préstamos a la entidad crediticia, y recibe de los prestatarios la cantidad de los intereses que no está cubierta por la ayuda estatal. Mientras que la decisión de las autoridades locales sobre si se concede o no la ayuda al interés de un préstamo para vivienda propia es tutelable ante la jurisdicción contencioso-administrativa provincial, la decisión de dicha concesión por parte del Fondo de vivienda de Finlandia cuando se trata de un préstamo para el alquiler de viviendas no lo es.

Vinculado igualmente a los mencionados préstamos de vivienda subvencionados estatalmente se encuentra el derecho de ocupación de una vivienda, garantizado por una Ley de 1990. Los beneficiarios de dicho derecho, otorgado por la autoridad local conforme a una serie de criterios y un procedimiento fijados reglamentariamente por el Gobierno nacional, deben formalizarlo en un contrato escrito con el dueño de un edificio construido, adquirido o renovado con préstamos subvencionados estatalmente y en el que se encuentra la vivienda objeto del derecho de ocupación. En dicho contrato deben fijarse, además, las cantidades a cuenta aportadas por los beneficiarios durante la construcción del edificio para cubrir la diferencia entre el coste real y el préstamo público (sin que puedan exceder en su total el 15\%), y las cuotas de comunidad residencial, que deben ser pagadas desde la fecha de comienzo de la relación contractual, en una cuantía correlativa adecuada a los gastos razonables de financiación y mantenimiento de la vivienda objeto del derecho de ocupación y de las instalaciones anejas, sin que pueda exceder la renta media pagara por las viviendas de semejante valor de uso en el mismo área urbana. Esta cantidad es actualizable periódicamente por el dueño de la vivienda conforme a unos criterios establecidos por la Ley, y es susceptible de impugnación ante la autoridad local por el beneficiario del derecho de ocupación.

Este derecho de ocupación puede ser transmitido por parte de su titular a la persona que haya sido autorizada por las autoridades municipales o a los integrantes de un listado de familiares directos (esposa, ascendientes y descendientes) fijados por la ley, bien gratuitamente, bien onerosamente a cambio de un precio que no excederá el valor de los pagos a cuenta efectuados, más un índice de actualización fijado estatalmente y el valor de 
la mejoras realizadas por el transmitente en la vivienda durante su ocupación de la misma. Las decisiones de la autoridad local relativas a la concesión, priorización, contenido, etc...., de este derecho de ocupación también son tutelables, una vez agotada la vía administrativa, ante la jurisdicción contencioso-administrativa provincial en única instancia, a excepción de la relativas al control municipal de las cantidades requeridas como contraprestación por la transmisión del derecho de ocupación, que no son impugnables.

Finalmente, por lo que se refiere a las ayudas destinadas a cubrir los costes derivados del disfrute de una vivienda, la Ley de ayudas a la vivienda de 1975, garantiza a toda unidad familiar cuyos miembros residan permanentemente en Finlandia una ayuda económica, con cargo a los Fondos de la Seguridad Social, para cubrir los gastos de la vivienda alquilada o en propiedad. Además de quienes no residan permanentemente en el país, también quedan excluidos de esta ayuda los estudiantes que perciban una ayuda de vivienda estudiantil suplementaria, las unidades familiares de dos o más personas cuando una de ellas ya sea perceptora de una ayuda de vivienda estudiantil, las unidades familiares unipersonales que reciban una ayuda de vivienda para pensionistas o las pluripersonales cuando alguno de los miembros reúna los requisitos para ser beneficiario de una ayuda de vivienda para pensionistas, así como las unidades familiares en las que alguno de sus miembros ya sea perceptor de una ayuda de vivienda para pensionistas. Los requisitos para recibir la ayuda de vivienda son que la vivienda sea apta para su uso como vivienda habitual, que la suma total de los ingresos mensuales permanentes de la unidad familiar no exceda las cantidades fijadas anualmente por el Gobierno y que la suma total del patrimonio fiscalmente sujeto de la unidad familiar, sin computar la vivienda habitual, no exceda las cantidades fijadas anualmente por el Gobierno. La cuantía de la subvención de vivienda cubre el $80 \%$ de los gastos razonables de vivienda que excedan un mínimo deducible fijado anualmente por el Gobierno en función del tamaño la vivienda, los miembros de la unidad familiar y la suma total de los ingresos mensuales permanentes de aquélla. Los gastos cubiertos en el caso de una vivienda alquilada incluyen el alquiler y los gastos de agua y de calefacción que, en su caso, se abonen separadamente. En el caso de una vivienda en propiedad se incluyen los gastos de agua y de calefacción, y los de comunidad, así como un porcentaje fijado anualmente por el Gobierno de los intereses anuales de los préstamos personales contraídos para su adquisición y de los préstamos subvencionados estatalmente concedidos para la adquisición de viviendas sociales. Los gastos se considerarán razonables siempre que se mantengan dentro de unas cantidades máximas por metro cuadrado, fijadas anualmente por el Gobierno en función de la localización, tamaño, antigüedad y nivel de servicios de la vivienda. Las decisiones del Instituto de la Seguridad Social sobre la concesión, requisitos, cuantía, etc..., de estas ayudas de vivienda son impugnables ante los juzgados de seguridad social, sin que quepa un ulterior recurso. 
En resumen, como se puede ver, el sistema escandinavo pretende ser omnicomprensivo de las necesidades de acceso a la vivienda de los ciudadanos residentes en el país. Diseña un sistema de ayudas que tratan de cubrir todas las necesidades de oferta y adquisición de vivienda, así como de acceso y disfrute de la vivienda en alquiler o a través de otros derechos de ocupación. Se trata así de evitar la situación de que haya personas que involuntariamente se encuentren sin acceso a una vivienda digna.

\section{EL DERECHO A UNA VIVIENDA DIGNA EN SISTEMA}

\section{CONSTITUCIONAL ESPAÑOL}

A) La garantía constitucional de un "derecho a la vivienda digna" en el artículo 47 CE. Su adscripción al modelo comparado de "principios rectores".

La CE reconoce en su art. 47 que "Todos los españoles tienen derecho a disfrutar de una vivienda digna y adecuada. Los poderes públicos promoverán las condiciones necesarias y establecerán las normas pertinentes para hacer efectivo este derecho, regulando la utilización del suelo de acuerdo con el interés general para impedir la especulación".

Este impropio "derecho" ligado al principio del Estado social (art. 1.1 CE), pero también al principio de dignidad de la persona y a su libre desarrollo (art. 10.1 CE), está también vinculado al respeto de los derechos a la integridad física y moral (art. 15 CE), a la intimidad (art. 18 CE), la libertad de residencia (art. $19 \mathrm{CE}$ ), el principio de igualdad formal (art. $14 \mathrm{CE}$ ) y material (9.2 CE), el derecho a la salud (art. $45 \mathrm{CE}$ ) o el derecho de propiedad y herencia (art. $33 \mathrm{CE}$ ). Esta conexión entre el derecho a la vivienda y otros derechos civiles o sociales hace que tanto algunas modalidades de acceso a la misma como, sobre todo, la garantía de su carácter "digno y adecuado" deban definirse teniendo en cuenta su relación con el resto de derechos constitucionales. Por otra parte, su garantía está ligada a la función social del derecho de propiedad (art. 33 CE), a la posibilidad de someter la libertad de empresa a las exigencias de la planificación (art. $38 \mathrm{CE}$ ), de reservar al sector público recursos o servicios esenciales (art. 128.2 CE) y de planificar la actividad económica general para atender necesidades colectivas (art. 131.1 CE), y a la subordinación, en definitiva, de todas las formas de riqueza al interés general (art. $128 \mathrm{CE}$ ).

A pesar de que el "derecho a la vivienda" aparece atribuido por el artículo 47 CE "a todos los españoles", su concreta configuración normativa como un principio rector y no un derecho constitucional o fundamental, no impide que, en virtud de lo dispuesto en el art. 13.1 CE, los concretos derechos subjetivos legales en los que se plasma se reconozcan, en consonancia con las exigencias de los instrumentos internacionales, también a los extranjeros y se atribuyan con independencia de la nacionalidad bien a todas las personas bien, en sintonía con la Carta Social Europea y el PIDESC, a colectivos en especial situación de vulnerabilidad o desventaja 
para el acceso a la vivienda, como atestiguan algunos Estatutos de Autonomía reformados y sobre todo las diversas leyes de vivienda de las Comunidades Autónomas. Así, la STC 107/1984, FJ 30, estableció ya en su día que el derecho a la vivienda sería uno de aquellos que pueden pertenecer o no a los extranjeros según lo dispuesto en tratados y leyes, y tanto aquéllos como la legislación autonómica -principal competente en materia de vivienda-, en conexión con el artículo $10 \mathrm{CE}$, referido a la dignidad y al libre desarrollo de las personas, y con el 9.2 CE, concerniente a la libertad e igualdad de los "individuos", lo han extendido a algunos grupos de extranjeros.

La CE sitúa el "derecho a una vivienda digna y adecuada" entre los "Principios rectores de la política económica y social" contenidos en el Capítulo III del Título I, rubricado como "De los derechos y deberes fundamentales". Respecto de ellos, el artículo 53.3 CE afirma que los principios rectores "informarán la legislación positiva, la práctica judicial y la actuación de los poderes públicos", y "solo podrán ser alegados ante la jurisdicción ordinaria de acuerdo con lo que dispongan las leyes que los desarrollen". Esta expresa limitación constitucional de su eficacia normativa guarda estrecha relación con su naturaleza de principios/derechos sociales, en los que, a pesar de su estructura normativa compleja, es determinante como elemento identificativo un contenido prestacional a cargo del Estado.

En efecto, lo característico de los denominados principios rectores de la política social y económica en general, y del "derecho" a la vivienda digna en particular, es que, además de implicar ciertas obligaciones de respecto o incluso de actuación regulatoria por parte de los poderes públicos -que según los casos y procedimientos podrían llegar a ser exigibles jurisdiccionalmente por la vía de la tutela de otros derechos fundamentales conexos-, su principal contenido normativo hace referencia a la obligación de los poderes públicos de articular prestaciones materiales y/o económicas que permitan la consecución del objetivo al que hace referencia el principio rector, en este caso el acceso de todas las personas que no puedan acceder por sus propios medios a una vivienda digna. $Y$ es precisamente en este aspecto prestacional, nuclear de su consideración como principios/derechos sociales, donde la fórmula de la justiciabilidad directa ex constitutione sin la previa creación legislativa de un derecho subjetivo a acceder a una prestación material en materia de vivienda, chocaría con la consideración de la Constitución Española de 1978, como una norma democráticamente abierta, que no es un programa a ejecutar por los poderes públicos (STC 11/1981, de 8 de abril, FJ $7^{\circ}$ y STC 209/1987, de 22 de diciembre, FJ 6º entre muchas), y que busca un adecuado equilibrio entre los poderes Legislativo, Ejecutivo y Judicial lo que exige en un Estado social y democrático de derecho que las decisiones sobre el gasto público, allí donde los recursos son escasos y la Constitución no ha establecido un expreso orden de prioridades, se adopten por el Parlamento y por el Gobierno, y no por los jueces y tribunales dado que los primeros están constitucionalmente habilitados para expresar las preferencias 
democráticas de las generaciones vivas sobre las prioridades de financiación de una pluralidad de fines y objetivos, todos de igual valor constitucional.

B) Eficacia jurídica limitada del derecho a la vivienda digna reconocido en el artículo $47 \mathrm{CE}$. Inexistencia de un derecho constitucional prestacional.

Como ya se dijo antes, el art. 53.3 CE expresamente afirma que los principios rectores del Capítulo III, entre los que se encuentra el "derecho" a la vivienda digna, "informarán la legislación positiva, la práctica judicial y la actuación de los poderes públicos", y "solo podrán ser alegados ante la jurisdicción ordinaria de acuerdo con lo que dispongan las leyes que los desarrollen". La jurisdicción constitucional ha interpretado esta última expresión como un elemento que condicionaría la exigibilidad judicial de los derechos del Capítulo III a la previa acción del legislador (STC 19/1982, de 5 de mayo, FJ 60, STC 45/1989, de 20 de febrero, FJ $4^{\circ}$ o STC 152/1988, de 20 julio, FJ $2^{\circ}$ ), pero se requieren algunas matizaciones en relación con la eficacia obligatoria de dichos principios rectores, y en particular del relativo a la vivienda digna, en atención a su compleja estructura normativa, que se ha ido poniendo de relieve.

En primer lugar, la inexistencia de un derecho subjetivo a obtener una determinada prestación por parte de los poderes públicos no implica la falta de eficacia normativa del principio rector, como en ocasiones se ha pretendido. Las normas constitucionales poseen todas ellas, incluidos los principios rectores de la política social y económica eficacia obligatoria, tanto interpretativa como derogatoria e incluso eficacia directa. Eficacia interpretativa, en la medida en que expresamente lo indica el art. 53.3 CE con la fórmula "informarán la legislación positiva, la práctica judicial y la actuación de los poderes públicos"; eficacia derogatoria, dado que, tal y como ha señalado el Tribunal Constitucional, las disposiciones infraconstitucionales que se opongan materialmente a lo previsto en los principios rectores del Capitulo III, quedan automáticamemte derogadas a la entrada en vigor de la CE de 1978; y eficacia directa porque, aunque no sean invocables por los ciudadanos directamente como derechos subjetivos ante los tribunales, sirven y han servido como parámetro para declarar la inconstitucionalidad de disposiciones postconstitucionales -incluso legales- que se oponen a lo por ellos dispuesto (así, por ejemplo, la STC 45/1989, de 20 de febrero, $F J 7^{\circ}$, respeto del mandato de protección a la familia).

En segundo lugar, es preciso tener en cuenta que, al igual que en el caso de los derechos fundamentales (recogidos en el Capítulo II del Título I $\mathrm{CE}$ ), también los principios rectores poseen una estructura normativa compleja que no se corresponde con la literalidad de su enunciado normativo. En este sentido, el "derecho" a la vivienda digna del artículo 47, es contenedor de mandatos al legislador, al ejecutivo y al poder judicial, pero también -en concordancia con otros derechos fundamentales conexos- de algunos derechos subjetivos no prestacionales. Las jurisdicciones contenciosoadministrativa, civil o penal, de hecho, recurren con frecuencia a medidas cautelares y otros instrumentos procesales en casos que podrían considerarse 
ligados al ejercicio del derecho a la vivienda. Así sucede, por ejemplo, cuando deben resolver la aplicación discriminatoria o la falta de información adecuada en ayudas o programas habitacionales, la realización de desalojos arbitrarios o la existencia de abusos de propietarios cometidos contra arrendatarios en situación de vulnerabilidad. Así, por ejemplo, el derecho a no ser privado de la propiedad privada de la vivienda habitual sin causa de utilidad pública o interés social, no es sólo expresión del art. 33 CE sino también conjuntamente del art. 47, y lo mismo cabe decir del derecho a exigir de los poderes públicos que regulen las condiciones de sonoridad, salubridad y habitabilidad adecuadas para la vivienda, a través del cual se protege tanto los derechos a la intimidad y la inviolabilidad del domicilio del art. 18.1 y 2 CE como el derecho a la vivienda digna del art. 47.

En efecto, la necesidad de desarrollo legislativo previo de los principios rectores para que éstos puedan ser invocados directamente ante los tribunales ha de ser matizada en dos sentidos:

$1^{0}$ únicamente se refiere a su invocación como derechos subjetivos prestacionales, directamente aplicables a partir del texto constitucional, y no a cualquier otra fórmula de invocación jurídico-argumentativa, como criterios interpretativos o como parámetros anuladores o derogatorios.

$2^{\circ}$ la razón de que el art. 53.3 CE tome la parte (las inexistentes facultades iusfundamentales de contenido prestacional) por el todo (cada uno de los principios rectores recogidos en el Capítulo III), al excluir que los principios del Capítulo III puedan ser directamente invocados ante los tribunales por los ciudadanos, reside en que, tal y como se puso antes de relieve, lo característico de los principios rectores en general -y del derecho a la vivienda en particular- es su carácter prestacional, es decir, las obligaciones prestacionales que pesan sobre los poderes públicos en orden a realizar distribuciones y atribuciones de recursos públicos para alcanzar el objetivo designado en el principio rector, en este caso facilitar el acceso a una vivienda digna y adecuada.

Con la fórmula limitativa de eficacia jurídica del art. 53.3 CE, el texto constitucional no habría querido sino impedir que, de las obligaciones prestacionales que se derivan de los mandatos impuestos por los distintos principios rectores, surgiesen de forma refleja -lo que es habitual en los clásicos derechos civiles y políticos- derechos subjetivos de carácter prestacional -en este caso a la vivienda digna- que alterarían el reparto de poderes entre los distintos órganos constitucionales y menoscabarían la eficacia de la Constitución si se pusiera en manos de órganos jurisdiccionales, carentes de legitimidad para expresar preferencias políticas, la decisión acerca de las políticas de gasto público sobre recursos escasos.

En resumen, aunque no quepa derivar de la Constitución la absoluta justiciabilidad de todos los contenidos del derecho a la vivienda, y en particular no sea posible exigir directamente ante los tribunales ningún derecho 
prestacional a la vivienda, lo cierto es que, de un lado, existen algunos aspectos del mismo que resultan perfectamente exigibles ante los tribunales ordinarios, que ya los tutelan de facto vinculados a otros derechos fundamentales, y, de otro lado, también cabe utilizarlo como parámetro interpretativo de las disposiciones legales y de la actuación administrativa y jurisdiccional, o como parámetro de validez y derogación de disposiciones de rango inferior a la Constitución cuando éstas son enjuiciadas por la jurisdicción constitucional o la ordinaria. Todo ello corrobora la eficacia jurídica limitada que poseen el "derecho" a la vivienda como principio rector de la política social y económica.

C) Posibilidad de creación autonómica de concretos derechos legales en materia de vivienda como desarrollo del artículo 47 CE.

¿Qué papel le corresponde, pues, dentro de este marco constitucional al legislador en el desarrollo y concreción de la garantía del derecho a la vivienda digna en España?

Es preciso aclarar como punto de partida que, conforme a la jurisprudencia del Tribunal Constitucional (entre muchas la STC 341/2005, de 21 de diciembre, FJ $4^{\circ}$, la STC135/2006, de 29 de abril, FJ $2^{\circ}$, y la STC 247/2007, de 12 de diciembre, $\mathrm{FJ} 13^{\circ} . \mathrm{a}$ ), las leyes, a las que hacen referencia el art. 53.3 CE o la expresión "normas pertinentes" que menciona el art. $47 \mathrm{CE}$, a través de las cuales los poderes públicos pueden adoptar las medidas necesarias para facilitar el acceso a la vivienda digna, no tienen por qué ser estatales (nacionales) o sólo estatales, y pueden y deben ser proyectadas y aprobadas por las Comunidades Autónomas, en cuanto competentes, conforme al art. 148.1.3 $\mathrm{CE}$, en materia de urbanismo y vivienda (STC 61/1997, de 20 de marzo, FJ. $\left.6^{\circ} . b\right)$.

En efecto, en el caso de mi Comunidad Autónoma, que tomo como ejemplo, el Principado de Asturias posee competencia exclusiva en materia de vivienda conforme al artículo 148.1.3. ${ }^{a}$ CE y al art. 10 de su Estatuto de Autonomía, aprobado por Ley Orgánica 7/1981, de 30 de diciembre. La regulación en materia de vivienda es, por tanto, necesariamente diversa territorialmente y, más allá de la necesaria coordinación interadministrativa (STC159/2001, de 5 de julio y STC 51/2004, de 13 de abril), sólo encuentra límites nacionales homogeneizadores, conforme a reiterada jurisprudencia constitucional (STC 152/1988, de 20 de julio y STC 59/1995, de 17 de marzo), en la competencia estatal para regular las condiciones básicas que garanticen la igualdad de todos los españoles en el ejercicio de los derechos constitucionales -lo que incluye el derecho a la vivienda- (art. 149.1. $1^{\text {a }} \mathrm{CE}$ ), en la competencia estatal sobre la legislación civil y procesal (art. 149.1. $6^{a}$ y $8^{a} \mathrm{CE}$ ), incluido lo relativo a la compraventa de vivienda, alquiler, desahucio, embargos, etc..., así como en otras competencias estatales de carácter transversal como planificación general de la economía, (art. 149.1.13 $\mathrm{CE}$ ), sanidad (art. 149.1.16a $\mathrm{CE}$ ), comunicaciones (art. 149.1.21 $\mathrm{CE}$ ), legislación básica sobre medio ambiente y sostenibilidad (art. 149.1.23 ${ }^{\mathrm{a}} \mathrm{CE}$ )..., que pueden incidir sobre el acceso y disfrute de una vivienda. 
En definitiva, las Comunidades Autónomas tienen capacidad legislativa y reglamentaria para emanar normas que afecten a la ordenación urbanística y a la vivienda. Es más, deben ser las que asuman el protagonismo sobre el diseño urbanístico de sus territorios, sobre el suelo y el "modelo de ciudad". También están habilitadas para regular causas de expropiación, las garantías que les correspondan, supuestos indemnizatorios específicos y procedimientos administrativos especiales; pueden definir y llevar a cabo una política de vivienda propia, complementando las actuaciones de protección y promoción previstas por el Estado con cargo a sus propios recursos (v. gr. viviendas de protección autonómica), o aplicando las medidas estatales adaptadas a las peculiares circunstancias de su territorio. Y, por último, pueden incluir en sus normas exigencias sobre estándares de calidad, zonas verdes, densidades de población, repartos de vivienda asequible entre los distintos municipios, previsiones especiales para determinados municipios en función de su tamaño poblacional y territorial, sus características similares, etc...

En ese sentido, hay que señalar que hasta el año 2006 el contenido del art. 47 CE se había desarrollado como un principio rector de la política social y económica únicamente en el plano de la legislación autonómica ordinaria en materia de vivienda. Con las últimas reformas de los Estatutos de Autonomía iniciadas en 2006, se ha producido un cambio, al menos formal, al introducirse en ellos una parte dedicada al reconocimiento de derechos. Así, por ejemplo, el reformado Estatuto de la Comunidad Valenciana en 2006 (y de forma similar el art. 22 del reformado Estatuto de las Islas Baleares de 2007) dispone en su art. 16 que "La Generalitat garantizará el derecho de acceso a una vivienda digna de los ciudadanos valencianos. Por ley se regularán las ayudas para promover este derecho, especialmente en favor de los jóvenes, personas sin medios, mujeres maltratadas, personas afectadas por discapacidad y aquellas otras en las que estén justificadas las ayudas". Quizá es el Estatuto que de manera más rotunda proclama con carácter general este derecho y la obligación de su garantía por loa Comunidad Autónoma. Sin embargo, no se traduce en el reconocimiento de un derecho subjetivo, sino en el imperativo de que por ley se regule un sistema de ayudas "para promover este derecho". La jurisprudencia constitucional, recaída en la STC 247/2007, de 12 de diciembre, $\mathrm{FJ}^{\circ}{ }^{\circ} 5^{\circ}$, por la que se enjuiciaba, entre otros, la inclusión de un catálogo de derechos estatutarios no vinculados a la organización de las instituciones de autogobierno sino a las competencias autonómicas, como la vivienda, pone de relieve cómo los mismos no pueden contener auténticos derechos subjetivos pudiendo contener auténticos derechos subjetivos y no pasarán de tener en el propio texto estatutario eficacia jurídica como principios rectores, cuya creación en desarrollo de los derechos reconocidos constitucionalmente corresponde, en su caso, al legislador autonómico.

El panorama normativo existente en materia de vivienda en España hoy en día es, por tanto, el siguiente: existen disposiciones estatales sobre la 
ordenación de la edificación (Ley 38/1999, de 5 de noviembre, de Ordenación de la Edificación) y sobre el suelo (Real Decreto Legislativo 2/2008, de 20 de junio, por el que se aprueba el Texto Refundido de la Ley de Suelo), y un plan estatal de vivienda aprobado para el período 2009-2012 por Real Decreto 2066/2008, de 12 de diciembre, al amparo de la competencia estatal en materia de planificación general de la economía, cuya ejecución en buena medida corresponde a las CCAA. Junto a ellas, algunas CCAA que han modificado sus Estatutos de Autonomía desde 2006, han incluido un derecho estatutario a la vivienda digna, con la eficacia de un principio rector, y prácticamente todas, han desarrollado el principio rector del derecho a la vivienda del art. 47 CE (y, en su caso, el de sus respectivos Estatutos de Autonomía) mediante Leyes o Decretos diversos en materia de ayudas de vivienda, requisitos del urbanismo y la edificación, etc... Solo Cataluña ha optado en el año 2007 por una Ley integral de vivienda, en la que se regulan conjuntamente aspectos relativos a la planificación urbanística, las políticas públicas en materia de vivienda y las concretas ayudas para el acceso y disfrute de una vivienda digna; y Andalucía, ha aprobado en este mismo año 2010 una Ley del derecho a la vivienda que, en la linea del modelo francés, pretende establecer un genérico derecho a la vivienda para quienes carezcan de medios para acceder por sí mismos a ella, de muy difícil exigibilidad jurisdiccional.

Por su parte, el Principado de Asturias, está preparando un Proyecto de Ley del derecho a la vivienda que, desde una perspectiva intermedia respecto de los dos ejemplos anteriores, pretende articular concretos derechos prestacionales y garantías de adecuación de la vivienda, exigibles de forma realista ante los tribunales. En esta línea, cabe añadir para concluir que de la abierta configuración constitucional, de la regulación internacional, pero sobre todo de los modelos de regulación comparada analizados, se pueden extraer los siguientes criterios que pueden servir de guía del posible contenido de una Ley del derecho a la vivienda dignan en el Principado de Asturias:

$1^{\circ}$ Las disposiciones urbanísticas y edificativas que garantizan un mínimo de salubridad, habitabilidad, infraestructuras y equipamientos comunitarios, ubicación, etc... de toda vivienda deben caracterizarse legislativamente como un instrumento de garantía de la adecuación o dignidad de la vivienda. Es más, sería recomendable que se extendiesen a todo tipo de vivienda que se ponga en el mercado para su libre acceso por los ciudadanos, incluidas las que se venden o alquilan en el mercado libre, a fin de evitar casos vergonzosos en los que se pongan en circulación viviendas que han perdido o que nunca han tenido por sí solas garantías de habitabilidad. Estas disposiciones tendrían la consideración de garantías organizativoprocedimentales para la satisfacción normativa del derecho a que las viviendas a las que se accede -sea por uno mismo o con ayuda de los poderes públicos- son adecuadas, y permitirían satisfacer parte del contenido normativo 
directamente obligatorio del derecho a la vivienda digna tal y como lo han configurado los tratados internacionales.

$2^{\circ}$ Por lo que se refiere a la acción del Estado de carácter material, no parece conveniente prever como en el modelo francés un genérico derecho prestacional a la provisión de una vivienda digna, tutelable jurisdiccionalmente, dadas las dificultades organizativo-presupuestarias para hacerlo efectivo. Es preferible, por su mayor realizabilidad gradual, que los poderes públicos (en este caso el Principado de Asturias), al modo y manera del modelo escandinavo, garanticen concretos derechos subjetivos a ciertas ayudas materiales de acceso y/o disfrute de la vivienda en función en todo caso de la necesidad/capacidad de los potenciales beneficiarios.

$3^{\circ}$ En relación con lo anterior, parece razonable que las concretas prestaciones materiales que se quieran garantizar en materia de vivienda se agrupen en dentro de una misma Ley de vivienda y se clasifiquen, tal y como hace el modelo germánico, en dos bloques: un bloque de ayudas para el acceso a la vivienda, que incluirían, como hasta ahora, las diversas modalidades de ayudas a los propietarios de viviendas para su adquisición o construcción de vivienda habitual, o a los propietarios para su construcción, renovación y posterior puesta en alquiler social; y un bloque de ayudas al disfrute y mantenimiento de la vivienda a la que se ha accedido a través del mercado libre o públicamente regulado, dentro del que se incluirían las ayudas al alquiler y en su caso a la satisfacción de las cargas inmobiliarias de la propiedad de la vivienda habitual, en función en todo caso de las necesidades/capacidad de la unidad familiar beneficiaria.

$4^{\circ}$ Su caracterización legal aconseja que todas ellas, como sucede en el modelo escandinavo, se caractericen como derechos subjetivos condicionados, pero que aquellos elementos (cuantías, requisitos, criterios de priorización, etc....) que determinan el concreto quantum de gasto presupuestario que los poderes públicos deben afrontar cada año para su concesión, se configuren normativamente como una condición suspensiva a determinar por el Gobierno reglamentariamente con las bases de convocatoria de cada modalidad de ayuda, de modo que puedan ajustarse a las disponibilidades presupuestarias y a la necesidad social de cada tipo de ayuda.

$5^{\circ}$ Sería recomendable, por último, para una más justa y proporcionada satisfacción del derecho a la vivienda adecuada que las ayudas no se concediesen, con carácter general, de forma lineal superada una ciertas barreras económicas por los solicitantes, ni fijando la cuantía de la ayuda en función de los grupos sociales de pertenencia del solicitante, sino que, tal y como reflejan los modelos alemán y escandinavo, se adecúen proporcionalmente a las concretas capacidades y necesidades de cada unidad familiar beneficiaria. Esto es, teniendo en cuenta, criterios como los ingresos de los beneficiarios, el tamaño y valor de la vivienda, el importe proporcional de los gastos a financiar hasta unos ciertos límites, etc... 


\section{BIBLIOGRAFÍA BÁSICA CONSULTADA}

BAAMONDE, María Emilia Casas; RODRÍGUEZ-PIÑEIRO, Miguel. Comentarios a la Constitución Española. XXX Aniversario. Madrid: Wolters Kluwer, 2008.

DIÉZ-PICAZO, Luis María; PONTHOREAU, M.-C. The Constitutional Protection of Social Rights - Some Comparative Remarks. European University Institute, Florencia, 1991.

I FONT, Judith Gifreu. Problemes actuals del dret urbanístic a Anglaterra: referència especial al dret a l'habitatge, la cohesió social i el medi ambient. Revista catalana de dret públic, №. 38, 2009.

KENNA, Padraic. El derecho a la vivienda en Europa: deberes positivos y derechos exigibles (según la jurisprudencia del Tribunal Europeo de Derechos Humanos). Revista de derecho político. № 74, 2009.

LECKIE, Scott (ed.). National perspectives on housing rights. Haia: Kluwer Law International, 2003.

MACHO, Ricardo Jesús García. Los derechos fundamentales sociales y el derecho a una vivienda como derechos funcionales de libertad. Revista catalana de dret públic, No. 38, 2009.

MAS, Joaquín Tornos. La Sentencia del Tribunal Constitucional 247/2007 y el sistema constitucional de distribución de competencias entre el Estado y las Comunidades Autónomas. Revista d'Estudis Autonomics i Federals. № 7, 2008.

MAUNZ, Theodor; DÜRIG, Günther (Eds.). Grundgesetz Kommentar. Band III: Art 20-69. Munique: C.H. Beck, 2010.

MENÉNDEZ, Ignacio Villaverde; RODRÍGUEZ, Paloma Requejo; CORRAL, Benito Aláez; SARASOLA, Ignacio Fernández; FREIJEDO, Francisco José Bastida; PRESNO LINERA, Miguel Angel. Teoría General de los Derechos Fundamentales en la Constitución Española de 1978. Madri: Tecnos, 2004.

MILLARD, Eric. Los controvertidos "derechos oponibles". Simposio FrancoAmericano de Filosofia del Derecho Publico. Universidad de Buenos Aires, 2008.

PALAZÓN, Mercedes Cuyás. Habitatge, drets socials i valors constitucionals (urbanisme, cohesió social, immigració i dret al medi ambient). Revista catalana de dret públic, No. 38, 2009.

PRADOS, Gerardo Pisarello. El dret a l'habitatge com a dret social: implicacions constitucionals, Revista catalana de dret públic. №. 38, 2009.

RUIZ, Gerardo José Ruiz-Rico. Una aproximación básica al derecho constitucional a la vivienda. In: Estudios sobre la Constitucion Española: homenaje al profesor Jordi Solé Tura. Vol. 2, 2008, p. 1409-1424.

SALVADOR, Ana Manero. El acceso a la vivienda. Comentario de las iniciativas del Consejo de Europa. Revista General de Derecho Europeo. № 14, 2007.

SOLÉ, Juli Ponce; TOMÀS, Domènec Sibina (Coords.). El derecho de la vivienda en el siglo XXI: sus relaciones con la ordenación del territorio y el urbanismo: con un análisis específico de la Ley catalana 18/2007, de 28 de diciembre, del derecho a la vivienda, en su contexto español, europeo e internacional. Madri: Marcial Pons, 2008.

ZACHER, Hans F. Zur sozialen Programmatik der Bayerischen Verfassung. In: Verfassung und Verfassungsrechtsprechung. Festschrift zum 25-jährigen Bestehen des bayerischen Verfassungsgerichtshofs. Munique: Richard Boorberg Verlag, 1972.

DIREITOS FundAMENTAIS E JUSTIÇA N 14 - JAN./MAR. 2011 